\title{
O gênero Anthidium Fabricius na América do Sul: chave para as espécies, notas descritivas e de distribuição geográfica (Hymenoptera, Megachilidae, Anthidiini) ${ }^{1}$
}

Danúncia Urban ${ }^{2}$

\begin{abstract}
The genus Anthidium Fabricius in the South America: key for the species, descriptive notes, and geographical distribution (Hymenoptera, Megachilidae, Anthidiini). The Anthidiini, in South America, is represented by a single genus Anthidium Fabricius, 1804 (type-species: Apis manicata Linnaeus, 1758). Thirty nine species are treated in this paper, as follows: Anthidium alsinai Urban, 2001; A. andinum Joergensen, 1912; A. anurospilum Moure, 1957 nom. reval. (formerly = A. espinosai Ruiz, 1938); A. atricaudum Cockerell, 1926; A. aymara Toro \& Rodríguez, $1998 ; A$. chilense Spinola, 1851; A. chubuti Cockerell, 1910; A. colliguayanum Toro \& Rojas, 1970; A. cuzcoense Schrottky, 1910; A. danieli Urban, 2001; A. decaspilum Moure, 1957; A. deceptum Smith, 1879; A. edwini Ruiz, 1935; A. espinosai Ruiz, 1938; A. falsificum Moure, 1957; A. friesei Cockerell, 1911; A. funereum Schletterer, 1890; A. garleppi Schrottky, 1910 = A. matucanense Cockerell, 1914 syn. nov.; A. gayi Spinola, 1851; A. igori Urban, 2001; A. larocai Urban, 1997; A. latum Schrottky, 1902; A. luizae Urban, 2001; A. manicatum (Linnaeus, 1758); A. masunariae Urban, $2001 ; A$. nigerrimum Schrottky, 1910; A. paitense Cockerell, 1926; A. penai Moure, 1957; A. peruvianum Schrottky, $1910 ; A$. rafaeli Urban, 2001; A. rozeni Urban, 2001; A. rubripes Friese, $1908=A$. boliviense Friese, 1920 syn. nov. $=A$. adriani Ruiz, 1935 syn. nov. = A. kuscheli Moure, 1957 syn. nov.; A. sanguinicaudum Schwarz, 1933; A. sertanicola Moure \& Urban, 1964; A. tarsoi Urban, 2001; A. toro Urban. 2001; A. vigintiduopunctatum Friese, $1904 ; A$. vigintipunctatum Friese, 1908, and $A$. weyrauchi Schwarz, 1943. Some taxonomic comments are made for each species, and new data on geographic distribution are also given. The females of A. andinum, A. igori, A. rozeni and the male of A. anurospilum are described for the first time. Identification keys (for males and females), as well as illustrations for almost all species, are provided.
\end{abstract}

KeYwords. Hymenoptera; Megachilidae; Anthidiini; Anthidium; taxonomy.

\section{INTRODUÇÃO}

FABRICIUS (1804) propôs o gênero Anthidium relacionando numerosas espécies e LATREILLE (1910) designou Apis manicata Linnaeus, 1758, como espécie-tipo. Moure (1947) propôs dois gêneros novos para espécies neotropicais descritas no gênero Anthidium: Tetranthidium para Anthidium latum Schrottky, 1902, e Stenanthidium para Anthidium espinosai Ruiz, 1938. Tanto Tetranthidium como Stenanthidium foram considerados por Michener (1948) como sub-gêneros de Anthidium, e colocados por GRISwOLD \& MicheNER (1988) na sinonímia de Anthidium (Anthidium). Segundo Michener (2000), o gênero Anthidium ocorre em todos os continentes excetuando a Austrália; as espécies neotropicais pertencem ao subgênero
A. (Anthidium) que, também, tem ampla distribuição geográfica. Para a identificação das espécies de Anthidium da América do Sul, Moure \& URBAN (1964) publicaram uma chave para a identificação de três espécies conhecidas do Brasil e TORO \& RodRíGUEZ (1998), incluíram em uma chave 15 espécies chilenas, comentando variações de padronagem e relacionando sinonímias, as quais são conservadas neste trabalho exceto a de A. anurospilum Moure, 1957 nom. reval.

O estudo dos espécimens da Coleção de Entomologia Pe. J. S. Moure, Departamento de Zoologia, Universidade Federal do Paraná (DZUP) levou à elaboração de chaves e diagnoses para as 39 espécies, sendo que a distribuição geográfica foi inserida na chave para os machos, e na das fêmeas, a ocorrência consta somente nas cinco espécies cujos machos são

\footnotetext{
1. Contribuição nº 1328 do Departamento de Zoologia, Universidade Federal do Paraná.

2. Departamento de Zoologia, Universidade Federal do Paraná, Departamento de Zoologia. Caixa Postal 19020, 81531-980 Curitiba - PR, Brasil. Bolsista do CNPq.
} 
desconhecidos: A. larocai, A. luizae, A. masunariae, A. tarsoi e $A$. weyrauchi. Por outro lado, de $A$. alsinai e de $A$. paitense, são conhecidos somente os machos. Não foram examinados os machos de $A$. colliguayanum e $A$. penai, nem a fêmea de $A$. weyrauchi, os quais foram incluídos nas chaves pelos caracteres descritos pelos autores. Quanto às variações na padronagem somente as não descritas anteriormente são comentadas neste trabalho; as novas ocorrências são assinaladas por um asterísco.

\section{Anthidium Fabricius, 1804}

Anthidium Fabricius, 1804: 364 (espécie-tipo: Apis manicata Linnaeus, 1758, por designação subseqüente).

Diagnose. Asas anteriores com a bifurcação da $\mathbf{M}$ e $\mathbf{C u}$ precedendo a anastomose da cu-a por distância aproximada de dois diâmetros da veia, sem arólios entre as garras, mandíbulas das fêmeas com mais de cinco dentes cônicos e profundamente entalhados, sexto tergo do macho com projeções laterais em forma de ganchos voltados para trás. Como os demais Anthidiini, com desenhos amarelos ou ferrugíneos no tegumento.

Chave para as espécies Sul-Americanas

\section{Machos}

1. Sétimo tergo com dois pares de projeções laterais digitiformes (Figs. 1,2) ... 2

Sétimo tergo com um par de projeções laterais espiniformes (Fig. 4, 6), digitiformes (Figs. 3, 5, 10) ou em forma de lóbulos achatados (Figs. 7, 8, 9, 11, 12)

2(1). Sétimo tergo com projeção mediana aguda e curta, as projeções digitiformes submedianas mais longas que as externas; quatro nódoas quadrangulares nos cinco tergos basais. EQUADOR (Guayaquil), PERU (Piura) ....A. vigintiduopunctatum Friese, 1904

Sétimo tergo com projeção mediana vestigial, as projeções digitiformes submedianas mais curtas que as externas; tergos com faixas amarelas. BRASIL (Maranhão, Ceará, Bahia, Espírito Santo, Minas Gerais, Goiás, Mato Grosso, São Paulo), PARAGUAI (Asunción), ARGENTINA (Tucumán, Misiones) A. latum Schrottky, 1902

3(1). Sétimo tergo com as projeções laterais e a mediana espiniformes e muito próximas, ocupando pequena área médio-apical, o tergo distintamente mais largo na base que no ápice das projeções laterais (Fig. 3)

Sétimo tergo com as projeções laterais e a mediana não como acima, quando espiniformes amplamente separadas por recorte basal, o tergo quase tão largo na base como no ápice das projeções laterais
(Figs. 4, 6) 5

4(3). Antenas e tégulas pretas; quinto tergo com faixa discal amarela ou amarelo-ferrugínea larga e com um pequeno recorte anterior em forma de V. PERU (Puno) A. nigerrimum Schrottky, 1910

Antenas e tégulas ferrugíneas; quinto tergo sem faixa amarela completa, com ou sem nódoas amarelas aos lados. CHILE (Tarapacá até Santiago) ......... A. espinosai Ruiz, 1938

5 (3). Escutelo e axilas com máculas amarelas (Fig. 30) ......... 6

Escutelo e axilas pretos, sem máculas amarelas ......... 13

6(5). Cinco tergos basais ornados com quatro máculas amarelas quadrangulares ou arredondadas ....... 7

Cinco tergos basais com faixa amarela completa ou com faixas laterais amarelas 9

7 (6). Vértice com faixa amarela. PERU (Lima), ARGENTINA (Santiago del Estero, La Rioja, Mendoza) .... A. vigintipunctatum Friese, 1908

Vértice com duas nódoas amarelas arredondadas ou estrias finas

8(7). Sétimo tergo com projeções laterais digitiformes mais longas que o dobro do comprimento do espinho mediano (Fig. 5); sexto esterno com dois pequenos recortes semi-circulares médio-apicais. PERU (Arequipa, Lima), CHILE (Tarapacá, Antofagasta) A. deceptum Smith, 1879

Sétimo tergo com lobos laterais largos, arredondados na ponta, pouco maiores que o espinho mediano (Fig. 33); sexto esterno sem recortes médioapicais. PERU (Piura, Lima)

A.paitense Cockerell, 1926

9(6). Vértice com duas nódoas laterais amarelas arredondadas ou duas estrias finas laterais; sétimo tergo com projeção mediana variável, nunca vestigial 10

Vértice com faixa ferrugínea atrás dos ocelos; sétimo tergo com projeção mediana vestigial (Fig. 6). BRASIL (Minas Gerais, Mato Grosso, São Paulo), PARAGUAI (Itapuá)

A. sertanicola Moure \& Urban, 1964

10(9). Pelo menos um tergo com faixa amarela completa (Figs. $10,12)$ .. 11

Tergos sem faixa amarela completa, com faixas laterais ou nódoas amarelas (Figs. 7,8) 12

11(10). Sétimo tergo ferrugíneo, os lobos laterais com o contorno externo arredondado (Fig. 12); ao menos três tergos com faixa amarela completa. 
SURINAME (Wanica), VENEZUELA (Santa Marta, Magdalena), COLOMBIA, BRASIL (Roraima, Amapá)

A. sanguinicaudum Schwarz, 1933

Sétimo tergo amarelo com borda preta, as projeções laterais espiniformes com o contorno externo reto; somente o quinto tergo com faixa amarela completa (Fig.10). CHILE (Antofagasta até a Região IX Araucanía), ARGENTINA (Chubut, Neuquén) A. chilense Spinola, 1851

12(10). Antenas ferrugíneas; fêmures enegrecidos no terço basal e no restante ferrugíneos, tíbias e tarsos ferrugíneos; sexto tergo preto. ARGENTINA (Chubut) A. danieli Urban, 2001

Antenas enegrecidas com o escapo amarelo ventralmente; fêmures castanho-enegrecidos, tíbias e basitarsos pretos com larga estria amarela na face externa; sexto tergo com duas faixas laterais amarelas (Fig. 8). ARGENTINA (Tucumán, La Rioja, Mendoza, Rio Negro) ..... A. friesei Cockerell, 1911

13 (5). Vértice com faixa amarela junto ao occipício 14

Vértice com duas nódoas arredondadas ou faixas amarelas laterais estreitas 16

14(13). Sétimo tergo com lobos laterais largos 15

Sétimo tergo com projeções laterais espiniformes muito finas e voltadas para o meio. ARGENTINA (Chubut), CHILE (Coquimbo a Magallanes) ........ A. chubuti Cockerell, 1910

15(14). Sétimo tergo com espinho mediano pouco mais curto que os lobos laterais e truncado no ápice; sexto esterno com os espinhos laterais mais curtos que os espinhos laterais do sexto tergo e alargados para a base; esternos com pilosidade enegrecida. CHILE (Atacama até Valparaíso), ARGENTINA (Buenos Aires, Neuquén, Chubut, Rio Negro) A. decaspilum Moure, 1957

Sétimo tergo com espinho mediano arredondado e muito curto; sexto esterno com espinhos laterais delgados e mais longos que os espinhos laterais do sexto tergo; esternos com pilosidade esbranquiçada. CHILE (Biobío a Curicó) .

A. edwini Ruiz, 1935

16(13). Fronte um pouco elevada medianamente; clípeo amarelo com fina margem preta ou com pequena área basal e a margem pretas ... 17

Fronte deprimida, não elevada medianamente; clípeo predominantemente preto, com áreas laterais amarelas unidas subapicalmente por fina estria (Fig. 25). ARGENTINA (Mendoza, San Luis) .....
A. andinum Joergensen, 1912

17 (16). Tergos sem faixas laterais amarelas; segundo ao quinto tergo com pequenas nódoas laterais ou com quatro fileiras de nódoas amarelas ................... 18

Tergos com faixas laterais amarelas, com ou sem faixa amarela completa .24

18(17). Segundo ao quinto tergo com quatro nódoas amarelas arredondadas, maiores que o dobro do diâmetro do ocelo (Fig. 9) . 19 Segundo ao quinto tergo sem o aspecto descrito acima, quando com quatro nódoas amarelas, as máculas menores que o diâmetro do ocelo .21

19(18). Sétimo tergo com lobos laterais mais largos que três vezes a largura do espinho mediano, o recorte entre os lobos e o espinho mediano um pouco mais largo que os lobos laterais e arredondado; pernas pretas com desenhos amarelos ........... 20

Sétimo tergo com lobos laterais estreitos, apenas sobrepassando a largura do espinho mediano, recorte entre o espinho mediano e os lobos maior que duas vezes o comprimento dos lobos e quase reto; pernas ferrugíneas. PERU (Lima) ...... A. igori Urban, 2001

20(19). Tégulas pretas; tíbias pretas; sétimo tergo com os lobos laterais angulosos na ponta, a margem externa suavemente arredondada (Fig. 9); sexto esterno com projeções laterais espiniformes curtas, bissinuoso no meio. EQUADOR (Azuay), PERU (Apurimac, Junín, Lima, Puno), BOLIVIA (La Paz, Potosi) ........ A. garleppi Schrottky, 1910

Tégulas ferrugíneas; tíbias enegrecidas com mácula amarela alongada; sétimo tergo com os lobos laterais arredondados, sem angulosidade apical; sexto esterno com lamelas laterais arredondadas largas, bordo quase reto no meio. PERU (Cuzco) A. cuzcoense Schrottky, 1910

21 (18). Tégulas, pernas e antenas pretas .22

Tégulas, pernas e antenas ferrugíneas .

22(21). Quinto e sexto tergos com nódoas amarelas maiores que os lobos laterais do tergo distal; basitarsos com pêlos longos enegrecidos, ocasionalmente alguns brancos nos anteriores. CHILE (Tarapacá até a Região XI [Região Aisén]), ARGENTINA (Tucumán, Neuquén, Mendoza) A. funereum Schletterer, 1890

Quinto e sexto tergos pretos ou só o sexto preto e o quinto com nódoas amarelas reduzidas; basitarsos com pêlos brancos longos. PERU 
(Arequipa, Lima, Tacna), CHILE (Tarapaca, Antofagasta, Ancash)

A. atricaudum Cockerell, 1926

23(21). Lobos pronotais amarelo-ferrugíneos; tergos pretos ou com nódoas laterais amarelas, as nódoas diminuindo de tamanho dos basais aos intermediários; sexto esterno com espinhos laterais mais curtos que o espinho mediano do tergo distal e sem o espinho mediano; sétimo tergo com os lobos retos dos lados e angulosos na ponta. CHILE (Coquimbo)

A.falsificum Moure, 1957

Lobos pronotais pretos; primeiro ao terceiro tergo com nódoas laterais amarelas, as nódoas aumentando de tamanho dos basais aos intermediários, quarto tergo com faixas amarelas laterais estreitas e quinto tergo com nódoas alongadas dorsais; sexto esterno com espinhos laterais mais longos que o espinho mediano do último tergo e com um espinho mediano projetado para baixo; sétimo tergo com os lobos divergentes para os lados e arredondados (Fig. 31). CHILE (Antofagasta) A. anurospilum Moure, 1957

24 (17). Pelo menos um tergo com faixa amarela completa .... 25 Tergos sem faixas amarelas completas

25(24). Somente o quinto tergo com faixa amarela completa; sétimo tergo os lobos laterais retos aos lados e a ponta voltada para trás . .26

Três tergos basais com faixa amarela completa; sétimo tergo com os lobos laterais arredondados no lado externo e a ponta voltada para o meio. PERU (Apurimac, Lima, Tacna), CHILE (Tarapacá, Atacama) .............A. peruvianum Schrottky, 1910

26(25). Pilosidade esbranquiçada; tergo basal com faixas laterais amarelas; fêmures ferrugíneos com área basal preta; escapo amarelo-ferrugíneo ........... 27

Pilosidade preta na metade dorsal da cabeça, dorso do mesosoma e todo o metasoma; tergo basal preto; fêmures pretos como ápice ferrugíneo; escapo preto. PERU (Puno)

A. alsinai Urban, 2001

27 (26). Mandíbulas pretas com ápice castanho-avermelhado; antenas pretas; $\mathbf{C}+\mathbf{S C}$ e $\mathbf{R}$ enegrecidas, com área ferrugínea basal; lobos pronotais pretos. PERU (Lima) . A. rozeni Urban, 2001

Mandíbulas amarelas com orla preta; antenas ferrugíneas, um pouco escurecidas no ápice; $\mathbf{C}$ + SC e R ferrugíneas; lobos pronotais ferrugíneo-amarelados. CHILE (Coquimbo até
Curicó) .......A. colliguayanum Toro \& Rojas, 1970

28(24). Sétimo tergo com as projeções laterais mais longos que o dobro do comprimento do espinho mediano, voltados para trás ou levemente encurvados para o meio 29

Sétimo tergo com os lobos laterais igualando o comprimento do espinho mediano, quando com o espinho mediano curto os lobos laterais angulosos nos cantos externos 31

29(28). Fêmures pretos na metade basal e no restante ferrugíneos; tíbias ferrugíneas; sétimo tergo preto, com os lobos laterais voltados para trás; sexto esterno sem recorte distal em forma de W

.. 30

Fêmures inteiramente pretos; tíbias pretas com a extremidade ferrugínea; sétimo tergo ferrugíneoacastanhado, com os lobos laterais encurvados para o meio; sexto esterno com recorte distal em forma de W largo e profundo. CHILE (El Loa) ..... A. toro Urban, 2001

30(29). Sétimo tergo com lobos laterais mais largos que o recorte basal côncavo; mandíbulas pretas com ápice castanho-avermelhado; escapo, tégulas e lobos pronotais pretos; sexto tergo com faixas laterais amarelas. PERU (Lima)

A. rafaeli Urban, 2001

Sétimo tergo com os lobos laterais mais estreitos que a metade da largura do recorte basal, este quase reto; mandíbulas amarelo-pálidas com os dentes e a margem castanhos; escapo amarelo ventralmente e ferrugíneo dorsalmente; tégulas ferrugíneas com mancha amarela; lobos pronotais ferrugíneos; sexto tergo preto. CHILE (Antofagasta, Atacama)

A. aymara Toro \& Rodríguez, 1998

31(28). Sétimo tergo com os lobos laterais angulosos, a margem externa mais longa que a interna (Fig. 7) ou digitiformes e mais longos que o dobro de sua largura. 32

Sétimo tergo com os lobos laterais tão longos como largos e arredondados. CHILE (Santiago, Coquimbo até Curicó) .......... A. penai Moure, 1957

32(31). Sétimo tergo com as projeções laterais largas e mais curtas que sua largura, a ponta externa angulosa; antenas e tégulas ferrugíneas; pernas castanhas nos artículos basais e ferrugineas no restante ......

33

Sétimo tergo com projeções laterais longas, digitiformes; antenas e tégulas pretas ou enegrecidas; pernas pretas com desenhos amarelos . BRASIL (Bahia, Minas Gerais, Goiás, 
Rio de Janeiro, São Paulo, Paraná, Santa Catarina)

A. manicatum (Linnaeus, 1758)

33(32). Esternos com pilosidade esbranquiçada ou branca; máculas amarelas dos tergos com microreticulação, quase foscas; fêmures castanhos só na base. CHILE (Coquimbo a Valdivia), ARGENTINA (Neuquén, Rio Negro)

A. gayi Spinola, 1851

Esternos com pilosidade castanha; máculas amarelas dos tergos sem micro-reticulação, brilhantes; fêmures castanhos pelo menos no terço basal. PERU (Cuzco), CHILE (Ñuble, O'Higgins, Chuquisaca, Santiago, Biobío), ARGENTINA (Salta, Tucumán, San Juan, Neuquén, Mendoza, Chubut), BOLÍVIA (La Paz)

A. rubripes Friese, 1908

\section{Fêmeas}

1. Clípeo amarelo com margem preta ou preto com nódoas amarelas . .2

Clípeo inteiramente preto .................................................. 18

2(1). Clípeo amarelo, com borda preta junto ao labro ............ 3

Clípeo em parte preto e em parte amarelo, quando predomina o amarelo com desenhos pretos junto à sutura epistomal

3(2). Vértice com faixa amarela; quinto tergo com faixas laterais amarelas; sexto tergo com duas grandes máculas amarelas de contorno irregular (Fig. 22)

A. friesei Cockerell, 1911

Vértice com nódoas laterais amarelas; quinto tergo com faixa amarela completa; sexto tergo preto (Fig. 19) A. chilense Spinola, 1851

4(2). Ápice de sexto tergo com quatro projeções espiniformes, angulosas ou arredondadas, as medianas separadas por recorte côncavo (Figs. 13 a 16 ). .

Ápice do sexto tergo com duas projeções espiniformes laterais (Figs. 21 a 24), ou sem espinhos laterais (Figs. 19, 20) . .8

5(4). Primeiro ao quinto tergo com faixas laterais amarelas, ou do primeiro ao terceiro com faixa amarela completa e os restantes com faixas laterais; sem desenhos amarelos no dorso do mesosoma ....... 6

Primeiro ao quinto tergo com quatro nódoas amarelas [Fig. 14]; dorso do mesosoma com desenhos amarelos A. deceptum Smith, 1879

6(5). Primeiro ao terceiro tergo com faixas laterais amarelas; tergo distal com recorte côncavo entre os espinhos laterais e entre os medianos ..... ... 7

Primeiro ao terceiro tergo com faixa amarela completa; tergo distal com o recorte sinuoso entre os espinhos medianos e os laterais, convexo junto aos medianos e côncavo junto aos laterais (Fig. 13) A. peruvianum Schrottky, 1910

7(6). Tergo distal predominantemente amarelo com as projeções espiniformes; paroculares pretas; antenas castanhas, tégulas com castanho e amarelo-pálido, pernas enegrecidas com ferrugíneo só nos basitarsos posteriores

A. toro Urban, 2001

Tergo distal preto (Fig. 18) com as projeções medianas arredondadas e as laterais angulosas; antenas, tégulas e pernas ferrugíneas. A. edwini Ruiz, 1935

8(4). Vértice com faixa amarela ou ferrugínea, completa ou fragmentada 9

Vértice com nódoas laterais amarelas arredondadas, ovaladas ou em forma de finas estrias laterais, estas terminando antes da área pós-ocelar ...... 11

9(8). Primeiro ao quinto tergo com faixa amarela completa, faixas laterais ou nódoas amarelas 10

Primeiro ao quinto tergo com quatro nódoas amarelas grandes dispostas em fileiras (Fig. 21)

A. vigintipunctatum Friese, 1908

10(9). Vértice com faixa amarela fragmentada; segundo ao quinto tergo com faixa amarela estreita ornada com sinuosidades na margem anterior; sexto tergo com pontos rasos grandes e esparsos, os espaços brilhantes e sem micro-reticulação. A. latum Schrottky, 1902

Vértice com faixa ferrugínea contínua; segundo e terceiro tergos com faixas amarelas laterais estreitas, quarto e quinto com máculas amarelas ovaladas laterais; sexto tergo com pontuação densa e irregular, espaços entre os pontos microreticulados .. A. sertanicola Moure \& Urban, 1964

11(8). Segundo ao quarto tergo com quatro nódoas amarelas dispostas em fileiras (Fig. 23) .

Segundo ao quarto tergo sem o aspecto descrito acima, com faixas amarelas ou faixas laterais amarelas

12(11). Dorso do mesosoma preto; vértice com nódoas laterais amarelas arredondadas

A. cuzcoense Schrottky, 1910

Dorso do mesosoma com desenhos amarelos; vértice com nódoas laterais amarelas alongadas

A. vigintiduopunctatum Friese, 1904

13(11). Dorso do mesosoma preto 14

Dorso do mesosoma com desenhos amarelos 15 
14(13). Flancos do tergo distal com angulosidades; tégulas e pernas enegrecidas; asas tingidas com castanho. PERU (Junín). A. masunariae Urban, 2001

Flancos do tergo distal com dois espinhos fortes voltados para o meio; tégulas e parte das pernas ferrugíneas; asas ferrugíneas na metade basal...... A. aymara Toro \& Rodriguez, 1998

15(13). Tergos sem faixa amarela completa, somente com faixas laterais amarelas .16

Pelo menos três tergos com faixa amarela completa ........ A. sanguinicaudum Schwarz, 1933

16(15). Escopa esbranquiçada; escapo e pedicelo enegrecidos; tégulas pretas com mácula amarela; tíbias e tarsos com o amarelo predominando 17

Escopa enegrecida; escapo e pedicelo ferrugíneos, tégulas ferrugíneas com mácula amarelo-palha; tíbias e tarsos ferrugíneos . A. danieli Urban, 2001

17 (16). Clípeo protuberante em perfil com desenhos amarelos reduzidos e pilosidade decumbente; sexto tergo com dentes finos nos flancos (Fig. 24) BRASIL (Mato Grosso) A. larocai Urban, 1997 Clípeo achatado quando visto de perfil, em grande parte amarelo, revestido com cerdas eretas onduladas na ponta; sexto tergo sem dentes laterais, apenas com angulosidades (Fig. 20)

A. manicatum (Linnaeus, 1758)

18(1). Clípeo e fronte com pilosidade decumbente ramificada

Clípeo e fronte com cerdas finas, eretas e onduladas na ponta A. andinum, Joergensen, 1912

19(18). Tergo distal com projeção espiniforme mediana fina e $\operatorname{curta}($ Fig. 17) 20

Tergo distal sem projeção espiniforme mediana ........ 21

20(19). Sexto tergo com as três projeções espiniformes amplamente separadas, a distância igualando três vêzes o comprimento das projeções; antenas e tégulas ferrugíneas .......... A. espinosai Ruiz, 1938

Sexto tergo com as três projeções espiniformes muito próximas, a distância inferior ao comprimento das projeções (Fig. 17); antenas em grande parte enegrecidas, escapo preto; tégulas enegrecidas

A. nigerrimum Schrottky, 1910

21(19). Tergo distal com dois pares de espinhos laterais e recorte mediano côncavo (Figs. 13 a 16) ........... 22

Tergo distal com um par de espinhos laterais ou somente com angulosidades laterais e recorte mediano variável

26

22(21). Antenas, tégulas e grande parte das pernas ferrugíneas; asas tingidas com ferrugíneo na metade basal, veias ferrugíneas até a metade da asa 23

Antenas, tégulas e pernas pretas; asas fracamente tingidas com castanho, veias enegrecidas ..... 24

23(22). Vértice com duas pequenas nódoas amarelas arredondadas atrás dos olhos; escopa esbranquiçada .................... A. penai Moure, 1957 Vértice com faixa amarela; escopa enegrecida A. chubutiCockerell, 1910

24(22). Tergos preto-pilosos ou com pêlos brancos só nos dois basais, tegumento preto ou com duas a quatro nódoas amarelas pequenas (menores ou igualando o diâmetro do ocelo); sexto tergo com nódoas amarelas mais longas que largas ou inteiramente preto .............................................. 25

Tergos com pilosidade branca, tegumento preto com quatro séries de nódoas amarelas irregularmente ovaladas, maiores que dois diâmetros de ocelo (com variação); sexto tergo com um par de máculas amarelas tão longas como largas ....... A. garleppi Schrottky, 1910

25(24). Tergos pretos com nódoas amarelas pequenas do terceiro ao sexto tergo raramente nos dois basais; sexto tergo com duas nódoas alongadas amarelas (Fig. 16); mandíbulas com cinco dentes; margem do clípeo quase reta e sem protuberâncias arredondadas ......... A. funereum Schletterer, 1890

Tergos inteiramente pretos ou com nódoas amarelas pequenas nos basais; sexto preto; mandíbulas com seis dentes; margem do clípeo marcada por recortes ornados com pequenas protuberâncias arredondadas ....... A. atricaudum Cockerell, 1926

26(21). Vértice com faixa amarela atrás dos ocelos, completa ou fragmentada 27

Vértice com nódoas laterais amarelas ou amareloesbranquiçadas 28

27 (26). Primeiro ao quarto tergo com faixas laterais amarelas largas com recorte posterior, no quinto tergo máculas grandes quadráticas

A. decaspilum Moure, 1957

Dois ou três tergos basais com nódoas amarelas bem laterais, pouco maiores no primeiro, quarto tergo preto, quinto com minúsculas manchas amarelas A. falsificum Moure, 1957

28 (26). Quinto tergo com faixa amarela completa 29 Quinto tergo preto ou com faixas amarelas laterais .. 32

29(28). Escopa esbranquiçada; cabeça com pilosidade predominante branca 30 
Escopa preta; pilosidade da cabeça quase toda preta. PERU (Ayacucho) A. luizae Urban, 2001

30 (29). Sexto tergo preto 31

Sexto tergo com duas grandes máculas amarelas A. rafaeli Urban, 2001

31(30). Basitarsos com faixa branco-pilosa densa ao longo do comprimento; faixa amarela do quinto tergo alargando gradativamente para os flancos A. colliguayanum Toro \& Rojas, 1970

Basitarsos sem faixa branco-pilosa densa ao longo do comprimento; faixa amarela do quinto tergo com pequenos alargamentos sub-medianos, porém não alargando nos flancos ...A. rozeni Urban, 2001

32(28). Sexto tergo preto 33

Sexto tergo com duas grandes máculas amarelas. PERU (Lima) A. tarsoi Urban, 2001

33(32). Primeiro ao quinto tergo com faixas laterais amarelas 34

Primeiro ao quinto tergo com quatro nódoas amarelas, no quinto as nódoas de cada lado unidas por fina estria . A. igori Urban, 2001

34(33). Escopa preta ou enegrecida Escopa esbranquiçada .35 A. gayi Spinola, 1851

35 (34). Tégulas ruivas, as antenas inteiramente ruivas ou desta cor ao menos na metade distal; pilosidade creme na metade dorsal da cabeça e no escapo .......... 36

Tégulas e antenas pretas; pilosidade preta na cabeça inclusive no escapo. PERU (Ancash)

A. weyrauchi Schwarz, 1943

36(35). Primeiro ao quinto tergo com faixas amarelas laterais, raramente com mácula amarelas laterais maiores que o dobro do tamanho dos ocelos...

A. rubripes Friese, 1908

Somente o primeiro tergo ou do primeiro ao terceiro tergo com pequenas nódoas laterais amarelas, menores ou igualando o tamanho dos ocelos, quarto ao sexto tergo pretos

.. A. anurospilum Moure, 1957

Anthidium alsinai Urban, 2001

Anthidium alsinai Urban, 2001: 539.

Conhecido só o holótipo. Clípeo amarelo com duas minúsculas manchas pretas próximas ao ramo transversal da sutura epistomal, escapo preto, nódoas laterais amarelas no vértice; flagelômeros basais e parte das pernas ferrugíneos; segundo ao quarto tergo com faixas laterais amarelas estreitas, no quarto as faixas em arco rebaixado, quinto tergo com faixa amarela completa ornada com recortes posteriormente e bissinuada na margem anterior; pilosidade predominante preta.

Distribuição geográfica. PERU: Puno, Puno (3900m).

Anthidium andinum Joergensen, 1912

(Figs 25-28)

Anthidium andinum Joergensen, 1912: 136.

Espécie conhecida anteriormente só pelo holótipo macho, coletado em Blanco Encalada, localidade próxima de Chacras de Coria, depositado no Museo de La Plata, Argentina e, conforme DuRANTE \& Díaz (1998) é um macho e tem etiqueta de fêmea. Pela primeira vez foi identificada uma fêmea com cerdas eretas finas e onduladas no clípeo, a qual é descrita a seguir.

Fêmea. Cabeça enegrecida ornada com duas pequenas nódoas amarelas nos cantos do vértice; antenas enegrecidas com o lado ventral castanho-claro do quarto flagelômero ao distal; mesosoma preto incluindo as pernas; tégulas castanhoescuras; asas tingidas com castanho e veias enegrecidas. Primeiro tergo com nódoas amarelas pequenas nos flancos; segundo ao quinto com faixas laterais amarelas e arqueadas, a parte mediana das faixas no disco dos tergos e a lateral mais para a base, mais estreitas no segundo e terceiro tergos, afastadas por uma distância quase igual ao comprimento do escapo nos dois basais, um pouco mais aproximadas no terceiro; sexto tergo com duas grandes máculas amarelas separadas por pequena área preta.

Pilosidade predominante branca passando a castanha no vértice e disco do mesoscuto; pêlos castanhos esparsos no disco do escutelo. Clípeo, toda a fronte e parte das paroculares inferiores junto ao clípeo com cerdas muito finas eretas e onduladas ou dobradas na ponta. Castanha nos tarsômeros anteriores e medianos e ferrugínea na face ventral de todos os basitarsos; castanha e semi-ereta do segundo ao sexto tergo, porém com pêlos brancos sobre o tegumento amarelo, excetuando o sexto tergo, com pêlos pretos esparsos sobre as nódoas claras; escopa amarelo-palha.

Clípeo achatado, fosco, micro-reticulado e com pontos pilígeros separados por pequena distância (um a dois diâmetros de ponto), a margem angulosa e ladeada por dentes obtusos; área supraclipeal e restante da fronte deprimidas, microreticuladas porém com os pontos mais dispersos que no clípeo. Mandíbulas com sete dentes, o interno forte. Sexto tergo com dois espinhos laterais e duas projeções medianas arredondadas separadas por pequena concavidade, o espaço serrilhado entre os espinhos laterais e as projeções medianas.

Comprimento $11,67 \mathrm{~mm}$; comprimento da asa a partir do esclerito costal 9,83mm; largura da cabeça 4,72mm.

O macho com o clípeo em grande parte preto, com duas grandes máculas amarelas laterais quase triangulares prolongadas subapicalmente em forma de estrias muito finas, o ápice finamente preto; mandíbulas com grande nódoa amarela; tégulas enegrecidas, pernas castanhas. Tergos como na fêmea, o distal castanho-escuro; esternos castanho-amarelados com 
áreas castanhas. Pilosidade como na fêmea quanto ao colorido, porém curta e fina no disco do clípeo, mais longa e esparsa na fronte. Clípeo achatado menos na ponta, brilhante e com pontos densos na parte apical, esparsos para a base; fronte deprimida, micro-reticulada e fosca com pontos como na fêmea.

Comentário. Distinta das demais espécies de Anthidium pela fronte deprimida, os machos pelo clípeo preto orlado com amarelo nos lados e na ponta, e a fêmea pelo clípeo achatado revestido por cerdas finas eretas de ponta dobrada em forma de gancho.

Distribuição geográfica. ARGENTINA: Mendoza, Blanco Escalada, *Cacheuta; *San Luis, P. de los Funes.

Anthidium anurospilum Moure, 1957 nom. reval. (Fig. 31)

Anthidium anurospilum Moure, 1957: 216; Toro \& Rodríguez, 1998: 70 (= Anthidium espinosai Ruiz, 1938).

Um macho, coletado no CHILE, Toconao, Mare, com os mesmos dados de coleta do holótipo fêmea, depositado no DZUP, é descrito a seguir.

Macho. Tegumento predominantemente preto, porém amarelo no clípeo, paroculares inferiores e mandíbulas, o clípeo com margem preta e as mandíbulas com os dentes castanhos passando a pretos na ponta; pequenas nódoas amarelas nos cantos do vértice e mancha obsoleta esbranquiçada pós-ocelar; antenas com escapo, pedicelo e os três flagelômeros basais ferrugíneos, restante castanho. Lobos pronotais pretos; tégulas, ápice dos fêmures, tíbias e tarsos ferrugíneos; asas com ferrugíneo na parte basal, restante castanho com as veias da mesma cor. Primeiro ao quinto tergo com nódoas amarelas laterais, nos dois basais as nódoas pequenas e nos flancos, um pouco maiores no segundo; no terceiro um pouco prolongadas dorsalmente e mais afastadas da base do tergo nos flancos; no quarto tergo formando faixas estreitas, arqueadas para a frente, finas e mais próximas entre si que as nódoas dos anteriores; e no quinto, as nódoas com a metade do tamanho das faixas do tergo anterior, com a ponta medial no disco do tergo e a lateral próxima à base; sexto e sétimo tergos pretos.

Pilosidade branca na cabeça e mesosoma, incluindo as pernas e também nos tergos basais; preta nos demais tergos, nos esternos e na área distal dos dois tergos basais.

Margem do clípeo côncava no meio. Sétimo tergo com espinho mediano fino e longo e os lobos laterais divergentes, com o dobro do comprimento do espinho mediano, arredondados na ponta. Sexto esterno com espinhos laterais longos como os do sexto tergo e um espinho mediano voltado para baixo.

Comprimento total $11,17 \mathrm{~mm}$; asa danificada na ponta; largura da cabeça $4,08 \mathrm{~mm}$.

O holótipo fêmea de A. anurospilum tem as antenas ferrugíneas por cima até o quarto flagelômero e os restantes castanhos, ventralmente ferrugíneas; tergos pretos, os três basais com pequenas nódoas amarelo-pálidas laterais, menores ou igualando o tamanho do ocelo, com o contorno irregular; sexto tergo com duas projeções espiniformes laterais com recorte mediano semicircular.

Comentário. Esta espécie assemelha-se a A. falsificum Moure, 1957, pela predominância do preto nos tergos, pelas tégulas e pernas em parte ferrugíneas. Entretanto, em $A$. falsificum os lobos pronotais são amarelo-ferrugíneos, o sexto esterno do macho não tem espinho médio-apical voltado para baixo e os lobos laterais do sétimo tergo são voltados para trás; na fêmea a margem do clípeo é quase reta ou em arco rebaixado medianamente. Moure (1957) comentou a extraordinária semelhança de A. anurospilum com A. espinosai Ruiz, 1938; referiu-se ao sexto tergo da fêmea de $A$. anurospilum, marcado distalmente por um recorte muito pequeno. A fêmea de $A$. espinosai tem a mesma padronagem que essa espécie, tanto no colorido do tegumento como na pilosidade, contudo difere pelo sexto tergo que tem uma projeção mediana espiniforme curta e muito fina.

Distribuição geográfica. CHILE: II Região, Antofagasta, Toconao, Mare.

Anthidium atricaudum Cockerell, 1926

(Figs 34, 36)

Anthidium piliventre Friese, 1925: 40 (nom. praeoc.); Friese,1930:127. Anthidium atricaudum Cockerell, 1926: 218.

Ao descobrir a homonímia FrIESE (1930) publicou uma correção, substituindo $A$. piliventre Friese, 1925 por $A$. atricaudum Cockerell, 1926.

Predomina o tegumento preto com nódoas amarelas nos cantos do vértice; antenas, tégulas e pernas pretas; tergos com duas a quatro nódoas amarelas muito pequenas, com variações. Macho com clípeo, paroculares inferiores e mandíbulas amarelas. Fêmea com o sexto tergo preto com dois pares de projeçães espiniformes laterais.

Pilosidade. Nas fêmeas quase toda enegrecida, com áreas branco-pilosas variáveis; nos machos, com predominância de pêlos brancos longos na cabeça, face ventral do mesosoma e basitarsos anteriores, vértice com pêlos castanhos; nos tergos enegrecida ou mesclada com branca nos dois basais, e mais raramente com pêlos brancos até o quarto tergo. Tanto nos espécimens do CHILE como nos do PERU, foram constatadas variações na presença ou ausência de nódoas amarelas nos tergos. Machos coletados na mesma data em Tarata, PERU, com as nódoas amarelas dos tergos variando de duas do primeiro ao terceiro tergo; quatro no segundo e terceiro e duas nos dois tergos seguintes; quatro do primeiro ao terceiro; quatro do primeiro ao quinto, ou duas nódoas minúsculas aos lados do primeiro ao sexto tergo. Nas fêmeas dessa mesma localidade foram vistas também variações nas máculas amarelas dos tergos. Foram constatados seis dentes nas mandíbulas das fêmeas, entretanto em um dos exemplares coletados em 

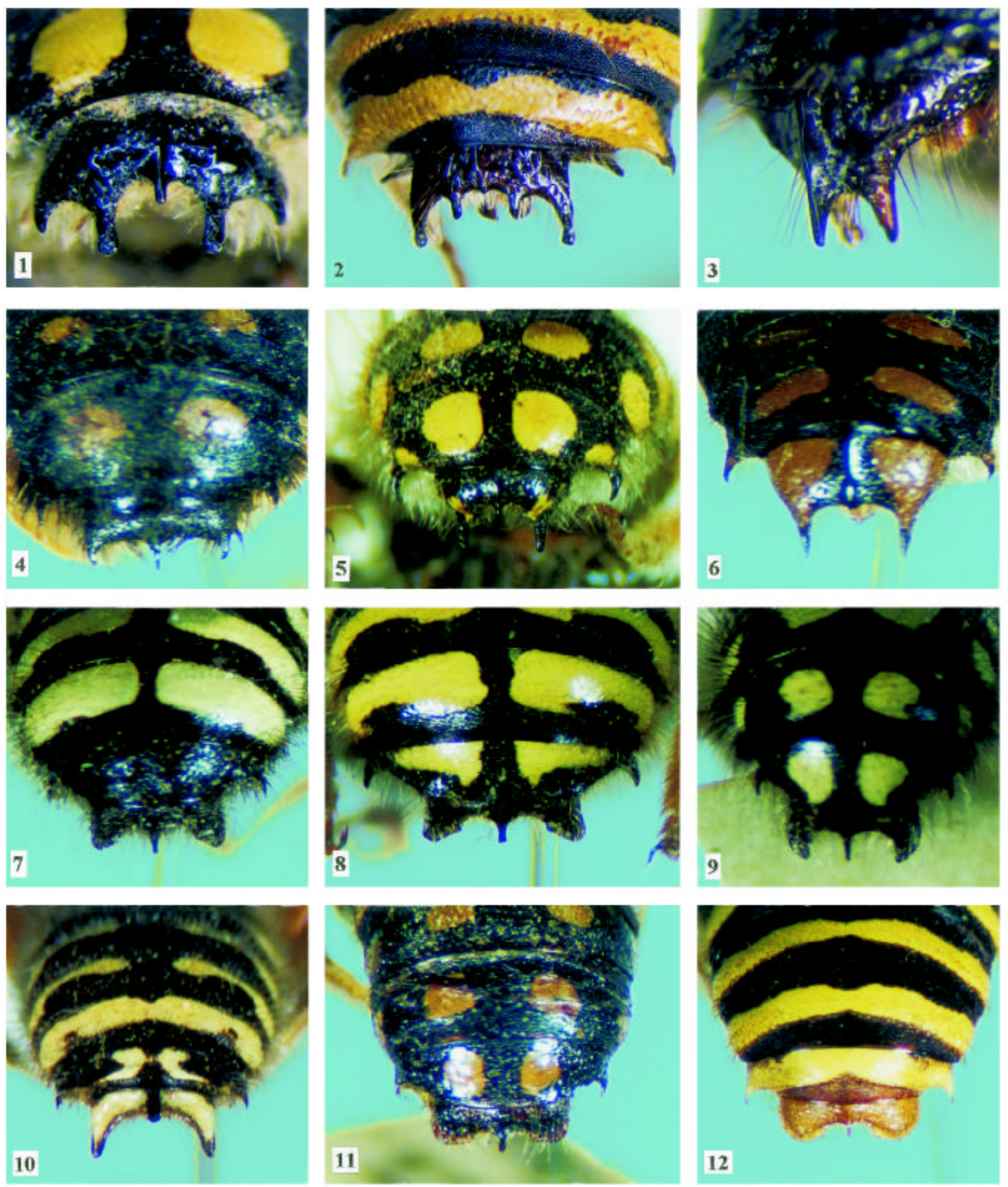

Figs. 1 - 12. Tergos distais dos machos. 1, A. vigintiduopunctatum; 2, A. latum; 3, A. nigerrimum; 4, A. chubuti; 5, A. deceptum; 6, A. sertanicola; 7, A. rubripes; 8, A. friesei; 9, A. garleppi; 10, A. chilense; 11, A. vigintipunctatum; 12, A. sanguinicaudum. 
Tumbre, CHILE foram encontrados sete dentes na mandíbula esquerda (Fig. 34) e seis na direita.

Distribuição geográfica. PERU: Arequipa, Yura; Tarata $(3.000 \mathrm{~m})$; Lima, Canta, San Mateo [perto de Matucana]; Tacna. *CHILE: I Região Tarapaca, Iquique; II Região, Antofagasta, Volcán Lascar, Tumbre (4000m).

\section{Anthidium aymara Toro \& Rodríguez, 1998 \\ Anthidium aymara Toro \& Rodríguez, 1998: 67.}

Vértice com nódoas laterais amarelas; antenas pretas, tégulas e pernas ferrugíneas; primeiro ao quinto tergo com faixas laterais amarelas, muito aproximadas dorsalmente. Macho com projeções laterais longas e digitiformes no sétimo tergo, medindo o dobro do comprimento da projeção mediana. Fêmea com a metade apical do clípeo amarela, a mácula triquetra discalmente, o sexto tergo com dois espinhos nos flancos.

Distribuição geográfica. CHILE: II Região, Antofagasta, Agua Verde, Paposo; III Região, Atacama, Potrerillos (acima de 2000m).

\section{Anthidium chilense Spinola, 1951}

(Figs. 10, 19)

Anthidium chilense Spinola, 1851: 181; Toro \& Rodríguez, 1998: 68.

Vértice com nódoas laterais amarelas; escutelo e axilas com máculas amarelas; antenas, tégulas e pernas ferrugíneas; tergos com faixas laterais amarelas, o quinto com faixa amarela completa. Macho com máculas amarelas no sexto tergo e o sétimo quase inteiramente desta cor. Fêmea com amarelo no clípeo e parte inferior das áreas paroculares, sexto tergo preto.

TORO \& Rodríguez (1998) incluíram A. mandibulare Schletterer, 1890 na sinonímia de $A$. chilense. Conforme informação pessoal de J. S. Moure, o tipo de A. mandibulare é uma Megachile e está depositado no Museu de Viena.

Distribuição geográfica. CHILE: II Região, Antofagasta até a IX Região, Araucanía. ARGENTINA: Chubut, Las Mercedes.

Anthidium chubuti Cockerell, 1910

(Fig. 4)

Anthidium chubuti Cockerell, 1910: 214; Toro \& Rodríguez, 1998: 69. Anthidium patagonicum Schrottky, 1910: 267; Cockerell, 1917: 252. Anthidium chubuti patagonicum; Moure, 1957: 206.

Anthidium gutierrezi Moure, 1957: 208; Toro, 1986: 126.

Vértice com faixa amarela; antenas, tégulas e pernas farrugíneas; tergos com faixas ou máculas laterais amarelas. Macho com o sétimo tergo armado com projeções laterais espiniformes voltadas para o meio. Fêmea com pilosidade enegrecida no clípeo, lado ventral do mesosoma e no metasoma, incluíndo a escopa, sexto tergo com dois pares de projeções, as medianas angulosas e as laterais muito delgadas.

A. chubuti foi descrita de Chubut, ARGENTINA, e $A$. gutierrezi do CHILE, Pemehue. Conforme Toro \& RodrígueZ (1998) Pemehue é uma localidade na Cordilheira, entre a VIII e a IX Regiões chilenas; estes autores observaram que nos exemplares de Punta Arenas, extremo sul do Chile, as nódoas amarelas dos tergos eram bastante reduzidas quando comparadas com as nódoas dos exemplares da zona central chilena. Foram examinados dois machos obtidos na mesma coleta, em Magalhanes, um com nódoas amarelas do primeiro ao quinto tergo e outro com o segundo e terceiro tergos inteiramente pretos.

Distribuição geográfica. CHILE: IV Região, Coquimbo, Río Laguna até a XII Região, Magallanes y de la Antártica Chilena, Punta Arenas, Laguna Amarga. ARGENTINA: Chubut, V. del Lago Xanco, Esquel; *Mendoza, Vellecitos; *Santa Cruz, Valle Tunel.

Anthidium colliguayanum Toro \& Rojas, 1970

Anthidium colliguayanum Toro \& Rojas, 1970: 147; Toro \& Rodríguez, 1998: 69.

Vértice com duas nódoas amarelas nos cantos; antenas, tégulas e pernas ferrugíneas; quatro tergos basais com faixas laterais amarelas, quinto com faixa amarela completa, esta com pequeno estreitamento mediano. Macho com os dois tergos distais pretos, o sétimo com os lobos laterais largos e arredondados. Fêmea com o sexto tergo preto, com um par de projeções angulosas bem laterais, escopa branca.

Distribuição geográfica. CHILE: IV Região, Coquimbo, La Serena, até a VII Região, Maule, Curicó.

Anthidium cuzcoense Schrottky, 1910

Anthidium cuzcoense Schrottky, 1910: 267.

Vértice com pequenas nódoas amarelas laterais; antenas pretas, tégulas ferrugíneas, pernas com preto e amarelo; tergo basal com manchas laterais amarelas grandes, segundo ao quinto tergo com quatro fileiras de máculas amarelas e sexto com duas máculas amarelas. Macho com o sétimo tergo preto, os lobos laterais arredondados na ponta. Fêmea com grande mácula amarela no clípeo e as paroculares inferiores também amarelas; sexto tergo sem espinhos laterais, só com angulosidades.

Distribuição geográfica. PERU: Cuzco (3500m).

Anthidium danieli Urban, 2001

Anthidium danieli Urban, 2001: 540.

Espécie reconhecida pelos desenhos amarelos do escutelo e cantos do vértice, tergos com faixas laterais amarelas ornadas com recorte posteriormente; antenas, tégulas e pernas ferugíneas em parte. Macho com os dois tergos distais pretos, o sétimo com lobos laterais largos; sexto esterno levemente arqueado para trás e com espinhos laterais curtos. Fêmea com máculas amarelas no clípeo e paroculares inferiores, angulosidades laterais no sexto tergo e escopa enegrecida.

Distribuição geográfica. ARGENTINA: Chubut, San Jorge.

Anthidium decaspilum Moure, 1957

Anthidium decaspilum Moure, 1957: 211; Toro \& Rodríguez, 1998: 69. 

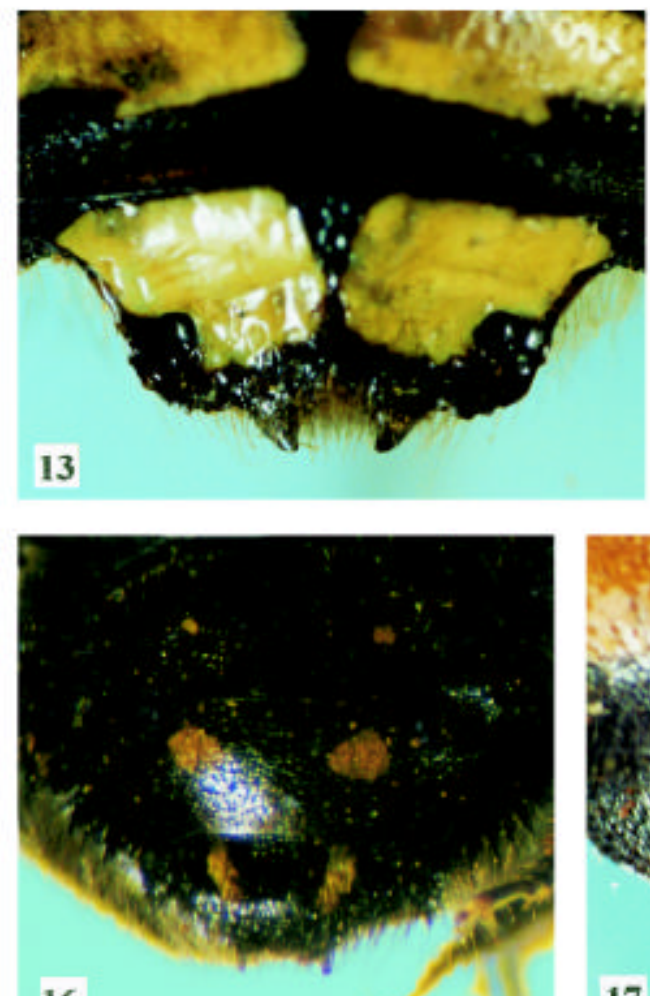

16
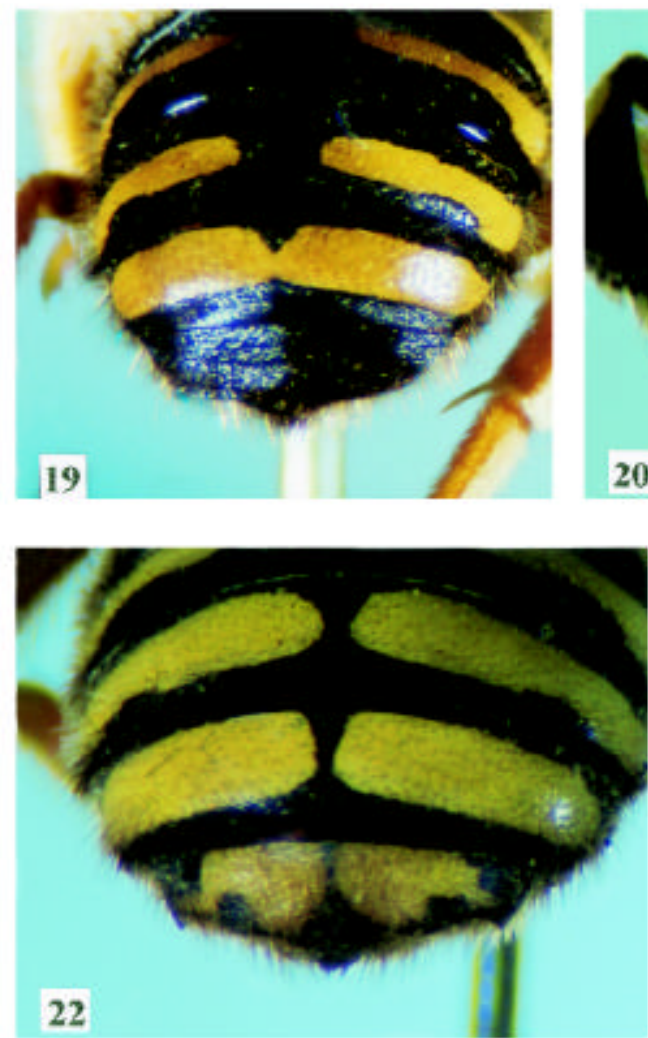
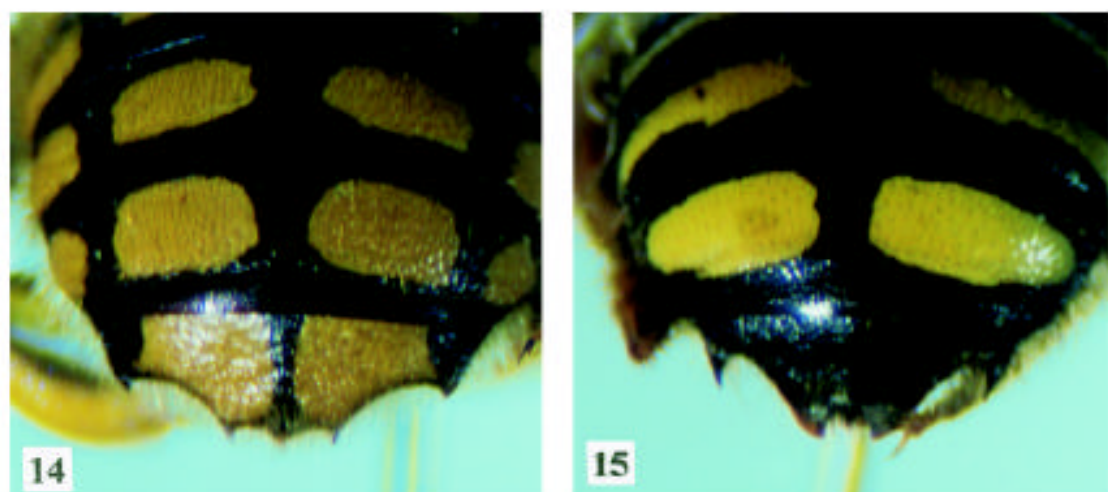

15
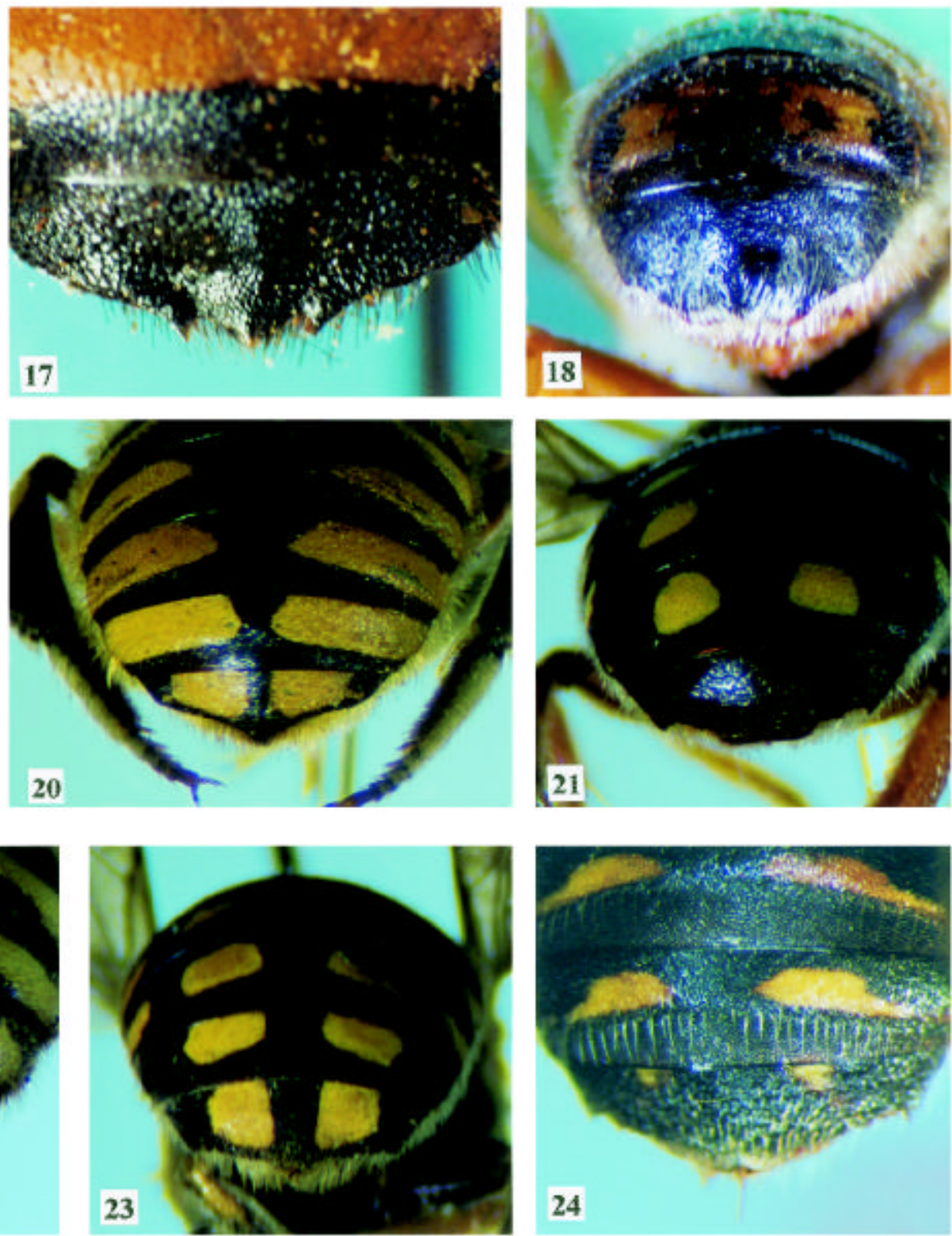

Figs. 13 - 24. Tergos distais das fêmeas. 13, A. peruvianum; 14, A. deceptum; 15, A. penai; 16, A. funereum; 17, A. nigerrimum; 18, A. edwini; 19, A. chilense; 20, A. manicatum; 21, A. vigintipunctatum; 22, A. friesei; 23, A. vigintiduopunctatum; 24, A. larocai. Na Fig. 13 somente os espinhos medianos e as áreas adjacentes. 
Vértice com faixa amarela; antenas, tégulas e pernas ferrugíneas; primeiro ao quinto tergo com faixas laterais amarelas, geralmente com recortes irregulares; lobos pronotais amareloferrugíneos. Macho com o sétimo tergo com os lobos laterais curtos e largos, margem externa mais longa. Fêmea com sexto tergo preto, com espinhos laterais pouco conspícuos, parte da margem serrilhada; escopa castanho-enegrecida. Como em $A$. falsificum, os machos com o pente cerdoso da borda do quarto tergo quase igualando o tamanho do escapo e o sexto esterno com a borda mediana projetada para trás em angulosidade e as fêmeas com pilosidade branca na cabeça.

Distribuição geográfica. CHILE: III Região, Atacama, Potrerillos; IV Região, Coquimbo, Baños del Toro, Quebrada Pastos, Embalse La Laguna, Río Laguna e $V$ Região, Valparaiso. *ARGENTINA, Neuquén, San Martín de los Andes; Chubut, Coronel Rivadavia; Río Negro, Lamarque; Buenos Aires. Parcialmente simpátrica com A. falsificum.

\section{Anthidium deceptum Smith, 1879}

(Figs. 5, 14)

Anthidium deceptum Smith, 1879: 19.

Anthidium aricensis Friese, 1904a: 182; Toro \& Rodríguez, 1998: 70. Anthidium simulans Cockerell, 1926: 217; Toro \& Rodríguez, 1998: 70.

SchwARZ (1943: 4-5), em nota no roda-pé, comentou a variação da área preta do clípeo das fêmeas de $A$. simulans e $A$. aricensis, sugeriu que talvez $A$. simulans poderia ser uma variedade de $A$. aricense e que $A$. simulans seria próxima de $A$. deceptum. A. simulans foi descrita de Tingo [Maria], PERU, $A$. deceptum do PERU e A. aricensis de Arica, CHLE.

Vértice com nódoas laterais amarelas; antenas pretas, tégulas e pernas com áreas pretas e amarelas; máculas amarelas no dorso do mesosoma; cinco tergos basais com quatro nódoas amarelas e no sexto somente duas. Macho com o sétimo tergo preto com projeções laterais digitiformes tão longas como os espinhos do sexto tergo. Fêmea com grande parte do clípeo e as paroculares inferiores amarelas, sexto tergo quase todo amarelo com dois pares de espinhos finos laterais separados por concavidade e no meio com dois pequenos lobos.

Foram constatadas variações no colorido do tergo distal do macho: de cinco exemplares coletados em Arequipa, PERU, um inteiramente preto, dois com nódoa amarela alongada nas projeções digitiformes laterais e dois com duas pequenas nódoas amarelas em cada projeção digitiforme. Entre machos coletados em Sobraya, Arica, norte do CHILE, foram vistos 15 exemplares com o tergo distal preto e três com nódoa amarela na base das projeções laterais. Também quanto ao tamanho, machos obtidos em uma mesma coleta medindo $10 \mathrm{~mm}$ até 13,8 mm de comprimento. As fêmeas com o clípeo amarelo com máculas pretas, nos exemplares de Arequipa a mancha preta é angulosa no disco e se estende até a sutura epistomal e, na maioria dos exemplares coletados em Tarapacá, CHILE, com duas nódoas pretas pequenas e triangulares junto à sutura epistomal.

Distribuição geográfica. PERU: Arequipa, Tingo [Maria]; *Tacna (500m); *Lima, San Bartolomé. CHILE: Região I, Tarapacá, Arica, Chaca, Sobraya; Região II, Antofagasta, Quillagua.
Anthidium espinosai Ruiz, 1938

Anthidium espinosai Ruiz, 1938: 153; Toro \& Rodríguez, 1998: 70. Stenanthidium espinosai; Moure, 1947: 16.

Anthidium (Stenanthidium) espinosai; Michener, 1948: 16.

Vértice com pequenas nódoas laterais amarelas; antenas, tégulas e pernas ferrugíneas; tergos pretos, só o primeiro ou os primeiros com nódoas amarelas aos lados. Macho com abas laterais arredondadas no sexto tergo, o sétimo com três projeções espiniformes no meio e carena mediana ao longo do comprimento. Fêmea com o sexto tergo projetado para trás angulosamente e com três espinhos, o mediano fino e curto, escopa preta. TORO \& RoDRíGUEZ (1998) observaram exemplares com variação na padronagem dos tergos, com nódoas amarelas grandes ou inteiramente pretos.

Distribuição geográfica. CHILE: Região I, Tarapacá, Putre até a IV Região, Coquimbo, Baños del Toro; Santiago, Farellones.

\section{Anthidium edwini Ruiz, 1935}

(Fig. 18)

Anthidium edwini Ruiz, 1935: 276; Toro \& Rodríguez, 1998: 70.

Vértice com faixa amarela; antenas, pernas e tégulas ferrugíneas; cinco tergos basais com faixas amarelas laterais largas, as faixas com recortes e pequenas nódoas discais pretas nos machos. Macho com os dois tergos distais enegrecidos, $\mathrm{o}$ apical com projeção mediana arredondada e curta e os lobos laterais angulosos, largos e muito curtos. Fêmea com manchas amarelas aos lados do clípeo e nas paroculares inferiores; sexto tergo com dois pares de projeções laterais arredondadas, as medianas separadas por recorte côncavo raso.

Distribuição geográfica. CHILE: VII Região, Maule, Los Queñes; VIII Região, Biobio, Fundo el Huingan.

Anthidium falsificum Moure, 1957

Anthidium falsificum Moure, 1957: 214; Toro \& Rodríguez, 1998: 70.

Vértice com nódoas laterais, faixas estreitas laterais ou faixa fragmentada amarela; antenas tégulas e pernas ferrugíneas; lobos pronotais ferrugíneos; tergos pretos ou com nódoas amarelas pequenas aos lados ao primeiro ou até do quarto tergo. Macho com os lobos laterais do sétimo tergo retos dos lados e angulosos na ponta externa; sexto esterno com espinhos laterais curtos. Fêmea com os espinhos laterais do sexto tergo pouco evidentes, parte da margem serrilhada, escopa castanhoenegrecida.

Variações constatadas no material-tipo: o holótipo fêmea com faixa amarela fragmentada e muito estreita no vértice, três primeiros tergos com nódoas amarelas bem laterais e o quinto tergo com duas nódoas dorsais; um parátipo fêmea com faixa amarela completa no vértice e outro somente com faixas laterais finas e as nódoas amarelas do quinto tergo muito reduzidas. Quanto aos machos, o alótipo com duas nódoas laterais amarelas no vértice e os dois tergos basais com máculas amarelas laterais; um parátipo que foi coletado com o alótipo com o metasoma inteiramente preto e outros dois com pequenas faixas amarelas 

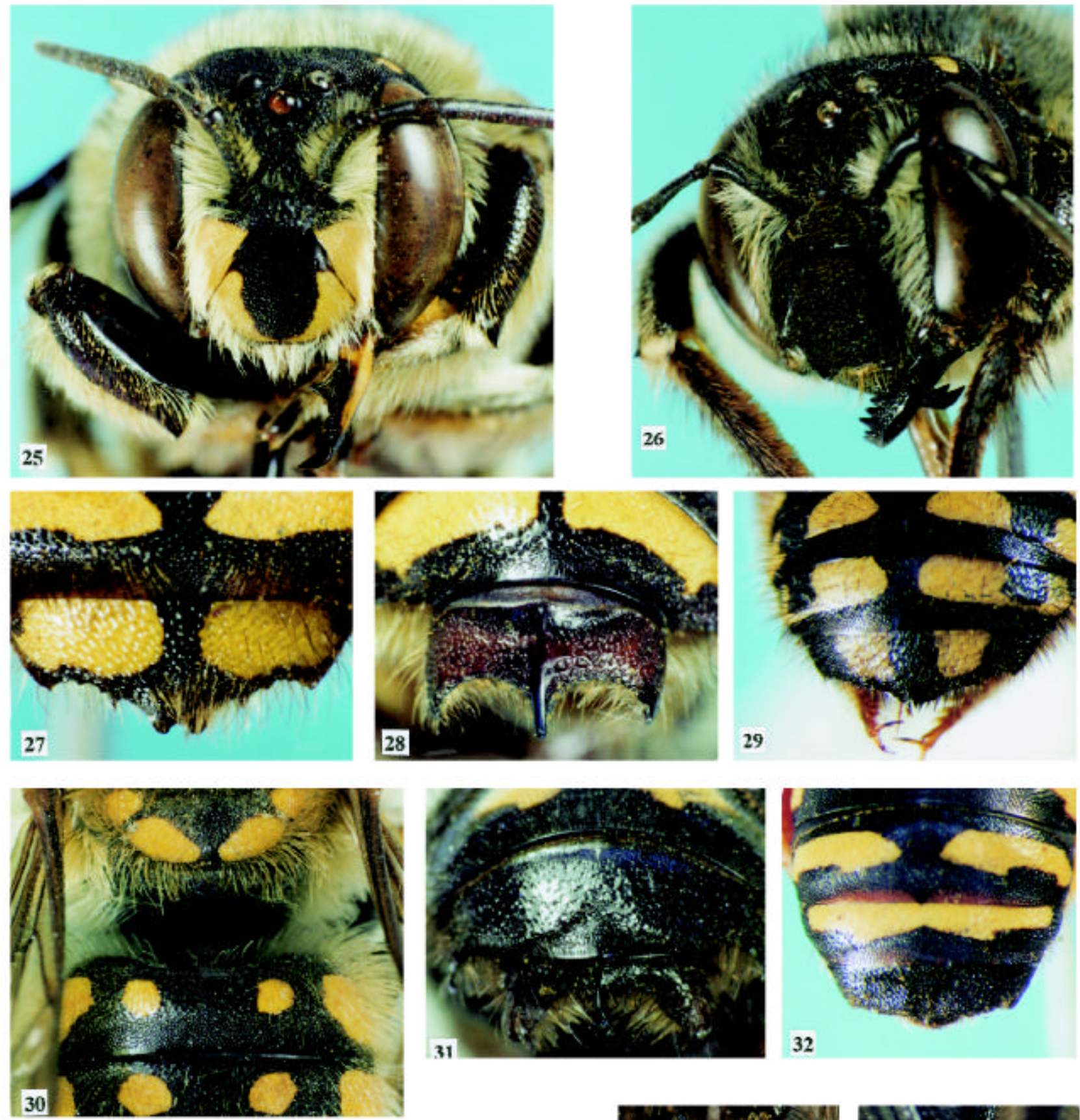

32
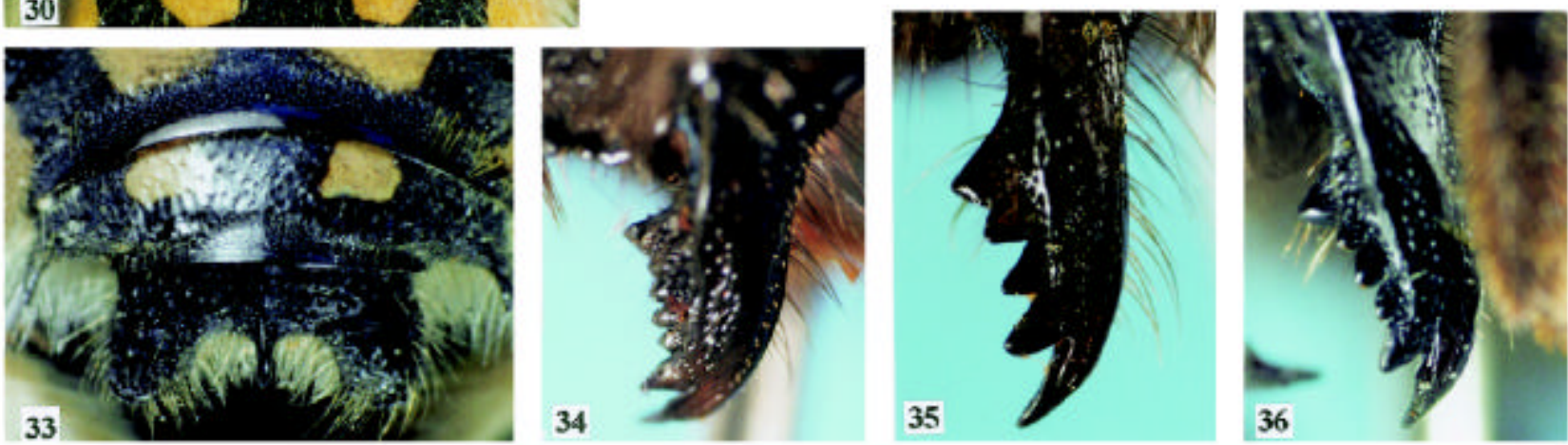

Figs. 25 - 36. 25 - 28, Anthidium andinum: 25, cabeça do macho; 26, cabeça da fêmea; 27, tergos distais da fêmea; 28, tergos distais do macho; 29, A. igori, tergos distais da fêmea; 30 e 33, A. paitense: 30, escutelo, axilas e tergos proximais do macho; 33, tergos distais do macho; 31, A. anurospilum, tergos distais do macho; 32, A. rozeni, tergos distais da fêmea. 34 a 36: mandíbula da fêmea; 34, A. atricaudum, anômala, com sete dentes, 36, mandíbula normal; 35, A. funereum. 
laterais no vértice.

Distribuição geográfica. CHILE: IV Região, Coquimbo, Baños del Toro (3000m), Quebrada Pastos, Río Seco.

\section{Anthidium friesei Cockerell, 1911}

(Figs. 8, 22)

Anthidium flavomaculatum Friese, 1908: 70 (nom. praeoc.).

Anthidium friesei Cockerell, 1911: 181 (nom. nov.).

Anthidium mendocinum Friese, 1917: 54 (nom. nov.).

Vértice com faixa amarela nas fêmeas e com finas estrias laterais nos machos; antenas enegrecidas, tégulas com amarelo e ferrugíneo; pernas com áreas pretas, ferrugíneas e amarelas; máculas amarelas no mesoscuto e escutelo; faixas laterais amarelas largas nos tergos, quase fundidas dorsalmente, no sexto tergo duas máculas irregulares também amarelas. Macho com sétimo tergo preto, lobos laterais com os lados paralelos, o externo mais longo e arredondado na ponta. Fêmea com um par de espinhos laterais agudos e muito curtos no sexto tergo, escopa amarelo-acastanhada.

As fêmeas examinadas foram coletadas em Rio Negro e La Rioja, têm faixa amarela completa no vértice e larga mácula em forma de $\mathrm{J}$ invertido aos lados do mesoscuto; um macho de Tucumán com as nódoas amarelas do vértice alongadas para o meio ocupando os dois terços laterais e pequenas máculas basais aos lados do mesoscuto; um de Mendoza e um de La Rioja com nódoas amarelas arredondadas nos cantos do vértice e o mesoscuto preto.

Distribuição geográfica. ARGENTINA: Tucumán; Mendoza; *La Rioja; *Rio Negro.

\section{Anthidium funereum Schletterer, 1890}

(Figs. 16, 35)

Anthidium funereum Schletterer, 1890: 231; Toro \& Rodríguez, 1998:71. Anthidium bombiforme Friese, 1920: 55; Toro \& Rodríguez, 1998: 71 (syn.).

Anthidium aterrimum Friese, 1925: 39; Toro \& Rodríguez, 1998: 71 (syn.).

Anthidium ruizi Reed, 1930: 375; Toro \& Rodríguez, 1998: 71 (syn.). Anthidium melanotrichum Friese, 1904b: 303; Moure, 1960: 7 (syn.).

Espécie reconhecida pela predominância do preto, tanto no tegumento como na pilosidade. Vértice com nódoas amarelas aos lados; antenas, tégulas e pernas pretas; tergos com pequenas nódoas amarelas. Sétimo tergo do macho com a margem externa dos lobos arqueada. Sexto tergo da fêmea com máculas amarelas, amarelo-escurecidas ou inteiramente preto, com quatro projeções espiniformes, as laterais mais afastadas das medianas e separadas também por recorte côncavo, escopa enegrecida.

Variações. Foram examinados 80 machos coletados em Alto Cantillana, Santiago, CHILE com um a quatro tergos inteiramente pretos, com duas pequenas nódoas amarelas do quarto ao sexto tergo, ou só no quinto e sexto; com quatro pequenas manchas amarelas do terceiro ao quinto e os dois tergos distais com duas pequenas nódoas amarelas; nódoas minúsculas nos dois tergos basais, o terceiro e o quarto pretos e os dois seguintes com nódoas laterais amarelas. Em alguns exemplares, o tergo basal com poucos pêlos brancos de permeio com a pilosidade preta. Fêmeas da mesma localidade com variações como nos machos: com duas nódoas laterais amarelas no tergo basal, quatro no segundo e terceiro e duas no quinto e sexto tergos; exemplares com um ou dois tergos basais pretos, duas máculas amarelas pequenas do terceiro ao quinto e o sexto tergo preto.

Distribuição geográfica. CHILE: Região I, Tarapacá até a Região XI, Aisén. ARGENTINA: Neuquén; * Mendoza, Villavicencio.

\section{Anthidium garleppi Schrottky, 1910}

(Fig. 9)

Anthidium garleppi Schrottky, 1910: 267.

Anthidium matucanense Cockerell, 1914: 314. Syn. nov.

Anthidium melanotrichum griseopilosum Friese, 1920: 54. Syn. nov.

Vértice com nódoas laterais amarelas; antenas, tégulas e pernas castanho-enegrecidas; cinco tergos basais com quatro fileiras de máculas amarelas. Macho com duas grandes máculas no sexto tergo, o sétimo tergo preto ou com pequenas manchas amarelas, os lobos laterais curvados para o meio; ápice do sexto esterno com recorte em W. Sexto tergo da fêmea com duas grandes nódoas amarelas e quatro projeções espiniformes. $\mathrm{O}$ síntipo macho de A. matucanense foi examinado por J. S. Moure no American Museum of Natural History, New York; $A$. melanotrichum griseopilosum foi colocado na sinonímia pelos caracteres da descrição. A.garleppi foi descrita de Apurimac e A. matucanense de Lima, PERU, A. melanotrichum griseopilosum de Cuenca, EQUADOR.

Espécie facilmente reconhecida pelas quatro fileiras de nódoas amarelas nos tergos; contudo, foram vistos machos com duas ou quatro nódoas amarelas no sexto tergo e, o sétimo tergo inteiramente preto, com duas pequenas manchas amarelas ou quase todo amarelo. Em um grupo de exemplares, quatro machos e três fêmeas, coletados em Tupiza, BOLÍVIA, foram observados dois machos com quatro máculas no tergo basal e dois com as máculas de cada lado fundidas formando faixas laterais com profundo recorte posterior; duas fêmeas com faixas laterais nos dois primeiros tergos como a dos machos e uma com faixas laterais amarelas do primeiro ao quinto tergo, as faixas estranguladas no meio.

Distribuição geográfica. PERU: Apurimac, Junín, Lima, Matucana; Puno. EQUADOR: Azuay, Cuenca. * BOLIVIA: La Paz, Copacabana ( $3.800 \mathrm{~m}) ;$ Potosi, Tupiza.

\section{Anthidium gayi Spinola, 1851}

Anthidium gayi Spinola, 1851: 180; Toro \& Rodríguez, 1998: 71. Anthidium coloratum Smith, 1854: 211; Herbst, 1907: 131 (syn.) Anthidium spinolae Gribodo, 1894: 204; Herbst, 1921: 104 (syn.)

Vértice com nódoas amarelas laterais; antenas, tégulas e pernas ferrugíneas; tergos com faixas laterais amarelas; lobos pronotais amarelo-ferrugíneos. Macho com o sexto e sétimo tergos pretos, lobos do sétimo tergo angulosos no lado externo. Fêmea com o sexto tergo preto e escopa esbranquiçada; macho com pêlos brancos nos esternos. 
Distribuição geográfica. CHILE: Região IV Coquimbo até a Região XI, Aisén.* ARGENTINA: Neuquén, Pto. Arrayanes; Rio Negro, Lago Moscardi.

Anthidium igori Urban, 2001

(Fig. 29)

Anthidium igori Urban, 2001: 542.

Somente o macho foi descrito, com nódoas amarelas nos cantos do vértice e quatro máculas amarelas em cada tergo, no quarto e quinto unidas posteriormente por uma estria fina; sétimo tergo com os lobos laterais tão delgados como o espinho mediano. Uma fêmea, coletada por Gerardo Lamas em Sto. Toribio, é descrita a seguir.

Fêmea. Cabeça preta incluindo as antenas, com duas nódoas amarelo-pálidas nos cantos do vértice; mesosoma e tégulas pretos; asas enegrecidas; pernas anteriores com coxas e fêmures enegrecidos e as medianas somente com as coxas enegrecidas, restante do tegumento ferrugíneo. Quatro tergos basais com quatro nódoas amarelas, o quinto com as nódoas de cada lado unidas por fina estria apical amarela; sexto com duas máculas amarelas grandes; as nódoas amarelas medianas e as laterais de cada lado do terceiro e quarto tergos com pequenas expansões apicais, como vestígios de uma fina estria.

Pilosidade branca, densa na cabeça e mesosoma; tíbias posteriores com pequena área apical branca denso-plumosa; no tergo basal branca e densa, com pêlos pretos curtos nas manchas amarelas dos tergos; escopa ventral creme nos esternos basais passando a enegrecida nos dois apicais.

Margem do clípeo finamente elevada e lisa, ligeiramente côncava no meio e com ondulações em direção aos dentes laterais; sexto tergo com um par de projeções laterais angulosas, sem aspecto espiniforme.

Comprimento total $10,5 \mathrm{~mm}$; comprimento da asa anterior a partir do esclerito costal $7,5 \mathrm{~mm}$; largura máxima da cabeça $4,0 \mathrm{~mm}$

Comentário. A fêmea desta espécie se distingue das espécies de Anthidium que têm quatro nódoas amarelas nos tergos, pelo tergo distal, somente com um par de espinhos laterais. A. cuzcoense, A. deceptum, A. garleppi, A. vigintipunctatum e $A$. vigintiduopunctatum têm dois pares de espinhos laterais no tergo distal e o clípeo em parte amarelo e em parte preto, exceto $A$. garleppi que tem o clípeo preto.

Distribuição geográfica. PERU: Lima, Canta $(2.800 \mathrm{~m}) ; *$ AN [Ancash], Sto Toribio, proximidades de Huaylan, $2.800 \mathrm{~m}$.

\section{Anthidium larocai Urban, 1997}

$$
\text { (Fig. 24) }
$$

Anthidium larocai Urban, 1997: 34.

Somente a fêmea foi descrita, tem o clípeo preto com estrias subapicais amarelas, margem lisa estreita, quase reta no meio e tubérculos aos lados; paroculares inferiores em parte amarelas; estrias amarelas finas nos lados do vértice; antenas em parte castanhas e em parte ferrugíneas; estrias finas amarelas no escutelo; tégulas enegrecidas com nódoa amarela; pernas com castanho, ferrugíneo e amarelo; tergos com com pontuação densa da base ao ápice, com faixas laterais amarelas estreitas, mais delgadas no meio, o distal com duas pequenas nódoas amarelas, com espinhos laterais finos e muito curtos; escopa branca.

Distribuição geográfica. BRASIL: Mato Grosso, Serra do Roncador.

\section{Anthidium latum Schrottky, 1902}

(Fig. 2)

Anthidium latum Schrottky, 1902: 447.

Anthidium codoense Ducke, 1907: 81; Ducke, 1910: 369 (syn.)

Anthidium insignissimum Strand, 1910: 544; Moure \& Urban, 1964: 108 (syn.)

Anthidium var. asuncionanum Strand, 1910: 545; Moure \& Urban, 1964: 108 (syn.)

Anthidium variegatipes Cockerell, 1927: 1; Moure \& Urban, 1964: 109 (syn.)

Tetranthidium latum; Moure, 1947: 15.

Vértice com faixa amarela completa ou fragmentada; antenas, tégulas e pernas como em $A$. larocai; escutelo com nódoas amarelas; faixas amarelas dos tergos estreitas e com o contorno anterior ondulado; pontuação densa na faixa apical do primeiro ao quinto tergo, para a base o tegumento brilhante e com pontos esparsos. Macho com o sétimo tergo preto, com dois pares de projeções digitiformes, as externas mais longas que as demais e o espinho mediano vestigial; clípeo com margem fracamente bissinuada. Fêmea com clípeo amarelo na metade apical, a margem em arco com pequenos tubérculos e a área apical desprovida de pontos um pouco inchada e mais larga que o diâmetro do ocelo mediano; sexto tergo com angulosidades nos cantos e faixa amarela discal; escopa branca.

Distribuição geográfica. BRASIL: Maranhão; Ceará; Bahia; Minas Gerais; Goiás; Mato Grosso; São Paulo. ARGEnTINA: Tucumán; Misiones. PARAGUAI: Asunción.

\section{Anthidium luizae Urban, 2001}

Anthidium luizae Urban, 2001: 544.

Somente a fêmea foi descrita, tem nódoas amarelas nos cantos do vértice, clípeo preto, antenas enegrecidas, tégulas e artículos distais das pernas ferrugíneos, faixas amarelas laterais ao primeiro ao quarto tergo, o quinto com faixa amarela completa; escopa preta.

Distribuição geográfica. PERU: Ayacucho, Puquio (3400m).

Anthidium manicatum (Linnaeus, 1758)

(Fig. 20)

Apis manicata Linnaeus, 1758: 577.

Anthidium manicatum; Fabricius 1804: 364; Moure \& Urban, 1964: 96.

Vértice com máculas laterais amarelas, antenas enegrecidas, tégulas e pernas com áreas enegrecidas e amarelas; tergos com faixas laterais amarelas, mais afastadas nos primeiros e muito próximas nos distais, com variação. Macho com tufos de cerdas aos lados dos tergos; sétimo tergo preto, com as projeções laterais digitiformes divergentes para os lados. Fêmeas com 
clípeo amarelo em parte e com mancha triangular ou triquetra preta junto à sutura epistomal, paroculares inferiores amarelas, sexto tergo com angulosidades aos lados; escopa branca.

Distribuição geográfica. BRASIL: Bahia; Minas Gerais; Rio de Janeiro; São Paulo; Paraná; Santa Catarina.

Anthidium masunariae Urban, 2001

Anthidium masunariae Urban, 2001: 545.

Somente a fêmea foi descrita, tem nódoas amarelas nos cantos do vértice, clípeo e paroculares inferiores em grande parte amarelos, antenas e tégulas pretas, pernas castanhoenegrecidas, faixas laterais amarelas do primeiro ao quinto tergo, as faixas com recorte posterior, sexto tergo preto com fracas angulosidades laterais; escopa branca nos dois primeiros esternos e enegrecida nos restantes.

Distribuição geográfica. PERU: Junín, Acolla (3460m).

\section{Anthidium nigerrimum Schrottky, 1910}

(Figs. 3, 17)

Anthidium nigerrimum Schrottky, 1910: 269.

Vértice com pequenas nódoas laterais amarelas, antenas e tégulas pretas, pernas com as tíbias e os tarsos ferrugíneos, tergos pretos menos o quinto com faixa amarela ou amareloferrugínea ocupando somente a parte dorsal do tergo e com contorno irregular. Macho com o sétimo tergo armado com três projeções espiniformes medianas muito próximas, como em $A$. espinosai. Fêmea com o sexto tergo armado com três espinhos pequenos angulosos em pequena área médio-apical; escopa preta.

Distribuição geográfica. PERU: Cuzco (3500m); Puno (3900m).

Anthidium paitense Cockerell, 1926

(Figs. 30, 33)

Anthidium paitense Cockerell, 1926: 217.

Conhecido somente o macho com com nódoas amarelas laterais no vértice, antenas pretas, tégulas e pernas com tegumento preto e amarelo, primeiro ao quinto tergo com quatro fileiras de nódoas amarelas, sexto com duas nódoas amarelas, sétimo tergo preto com lobos laterais largos e arredondados.

Distribuição geográfica. PERU: Piura, Paita [costa norte do Peru]; * Lima, Chontay, Valle del Lurin.

Anthidium penai Moure, 1957

(Fig. 15)

Anthidium penai Moure, 1957: 209; Toro \& Rodríguez, 1998: 72.

Vértice com pequenas nódoas laterais amarelas; antenas, tégulas e pernas ferrugíneas; faixas amarelas laterais nos tergos. Macho com as faixas laterais amarelas emarginadas posteriormente, sexto e sétimo pretos, o sétimo com lobos laterais arredondados. Fêmea com o sexto tergo armado com dois espinhos laterais finos e alongados e duas projeções angulosas medianas separadas por recorte semi-circular; escopa branca.

Distribuição geográfica. CHILE: Região IV, Coquimbo, até a Região VII, Maule, Cordilheira de Curicó.

Anthidium peruvianum Schrottky, 1910

(Fig. 13)

Anthidium peruvianum Schrottky, 1910: 267; Toro \& Rodríguez, 1998:72.

Vértice com pequenas nódoas laterais amarelas; antenas, tégulas e pernas pretas; três primeiros tergos com faixa amarela, os dois seguintes com faixas laterais amarelas emarginadas posteriormente. Macho com faixas aos lados do sexto tergo, sétimo preto com os lobos laterais voltados para o meio, a borda serreada entre os lobos e o espinho mediano; sexto esterno com espinhos laterais dirigidos para baixo. Fêmea com clípeo preto ou com máculas amarelas laterais; quarto e quinto tergos com faixas amarelas laterais com emarginação, tergo distal com grandes manchas amarelas e os espinhos laterais separados dos medianos por área arredondada

Distribuição geográfica. PERU: Apurimac; Lima, Canta. CHILE: Região I, Tarapacá, Putre; Região II, Antofagasta, El Loa, Saltar; Região III, Atacama, Tarata $(3000 \mathrm{~m})$.

Anthidium rafaeli Urban, 2001

Anthidium rafaeli Urban, 2001: 546.

Vértice com nódoas laterais amarelas; antenas e tégulas pretas; pernas em grande parte ferrugíneas; tergos com faixas laterais amarelas. Macho com o sétimo tergo armado com lobos laterais mais longos que o dobro do recorte basal e o sexto esterno armado com espinhos laterais finos e longos. Fêmea com as faixas laterais amarelas do quinto tergo unidas posteriormente, sexto tergo com duas grandes máculas amarelas e dois espinhos finos bem laterais; escopa amarelo-palha com pêlos castanhos nos dois esternos distais.

Distribuição geográfica. PERU: Lima, Canta (2800m).

Anthidium rozeni Urban, 2001

(Fig. 32)

Anthidium rozeni Urban, 2001: 547.

Vértice com nódoas amarelo-esbranquiçadas nos cantos; tégulas e parte das pernas ferrugíneas, tergos com faixas laterais amarelas com recortes posteriormente, o quinto tergo com faixa amarela completa, com ornamentações finas na margem posterior e recorte mediano em $V$ na margem anterior. Macho com antenas pretas; sexto e sétimo tergos pretos, o sétimo com lobos laterais arredondados. Pela primeira vez, foi examinada uma fêmea, a qual é descrita a seguir.

Fêmea. Tegumento predominantemente preto; cabeça com duas nódoas amarelo-esbranquiçadas nos cantos do vértice; lado ventral das antenas, a partir do terceiro flagelômero, ferrugíneo; pernas ferrugíneas com as coxas enegrecidas e, nas anteriores, também os trocanteres; tégulas e base das asas 
ferrugíneos. Tergos com faixas laterais amarelas, ornadas com recorte posterior, mais próximas dorsalmente no primeiro e no quarto tergos e mais afastadas no segundo e terceiro; quinto tergo com faixa amarela completa com a borda posterior em ângulo obtuso muito aberto com pequenos recortes angulosos laterais e reta em direção aos flancos; sexto tergo preto.

Pilosidade esbranquiçada esparsa na cabeça e mesosoma; tíbias posteriores com pequena área apical branca densoplumosa; basitarsos sem área denso-pilosa na face externa; escopa esbranquiçada. Margem do clípeo finamente elevada e ligeiramente convexa no meio; sexto tergo com um par de projeções laterais angulosas fracas.

Comprimento total 9,2mm; asas anteriores incompletas; largura da cabeça $3,4 \mathrm{~mm}$.

Comentário. A. rozeni, $A$. luizae, $A$. rafaeli e $A$. colliguayanum, têm faixas amarelas laterais nos quatro tergos basais e faixa completa somente no quinto tergo. Estas espécies se distinguem de $A$. rozeni pelos seguintes caracteres: $A$. luizae tem a escopa ventral preta; $A$. rafaeli, tem duas grandes nódoas amarelas no sexto tergo e $A$. colliguayanum tem área branca denso-pilosa ao longo da face externa dos basitarsos e a faixa do quinto tergo com a borda posterior reta.

Distribuição geográfica. PERU: Lima, Canta (2.800m).

\section{Anthidium rubripes Friese, 1908}

(Fig. 7)

Anthidium rubripes Friese, 1908: 70.

Anthidium boliviense Friese, 1920: 54. Syn. nov.

Anthidium adriani Ruiz, 1935: 277. Syn. nov.

Anthidium kuscheli Moure, 1957: 213. Syn. nov.

FrIESE (1908) descreveu A. rubripes da ARGENTINA, Mendoza, Salta e de Tucumán, J. S. Moure viu numerosos síntipos, incluindo um macho com a etiqueta vermelha, no Museum für Naturkunde der Humboldt-Universität zu Berlin, a identificação foi embasada na descrição e comparação de exemplares, macho e fêmea coletados em Mendoza, em 15/ XI/ 1908. Friese (1910) citou-a de Neuquén, ARGENTINA e Rancágua no CHILE e, ao descrever Anthidium boliviense de Mapiri, [La Paz] BOLÍVIA, comentou sua semelhança com fêmea de $A$. rubripes, distinguindo-a pela aparência mais fosca do mesoscuto, detalhes da borda do clípeo e pilosidade preta longa nos tergos. J. S. Moure examinou no mesmo Museu o síntipo de $A$. boliviense. RuIz (1935) deu a conhecer fêmea e macho de $A$. adriani, do CHILE, com antenas e pernas ruivas, tégulas e veias testáceo-avermelhadas e escopa negra; e posteriormente (RUIZ, 1940) transcreveu a descrição de $A$. rubripes porém; ao efetuar a versão para o espanhol interpretou "Segment 1 - 5 jederseits mit grossen gelben Bindenfleck", [segmentos 1 - 5 com largas faixas laterais amarelas] como "Segmento I - V con una ancha banda amarilla" [com uma larga faixa amarela]. Diante disso, comentou que embora tivesse material abundante do Chile não encontrou representantes desta espécie. Moure (1957) descreveu A. kuscheli de Poroma, CHILE, cujo material-tipo está depositado no DZUP e não difere dos demais exemplares examinados.

Vértice com nódoas laterais amarelas; antenas, tégulas e pernas ferrugíneas; lobos pronotais ferrugíneos; cinco tergos basais com faixas laterais amarelas largas e sem recortes, o tegumento liso nas máculas amarelas dos tergos. Macho com pilosidade preta nos tergos, sexto e sétimo tergos pretos, o sétimo com lobos laterais mais curtos que largos e a margem externa mais longa e levemente angulosa; ápice do quarto esterno com pente cerdoso mediano tão longo como a metade do comprimento do escapo; sexto esterno com o bordo quase reto entre os espinhos laterais. Fêmea com o tergo distal preto, com um par de espinhos laterais; clípeo com pilosidade preta; escopa enegrecida.

Variações foram constatadas nos machos e fêmeas coletados no CHILE e ARGENTINA, tanto no formato das áreas amarelas dos tergos, como faixas laterais ou máculas, como a distância entre as mesmas e até ausência de máculas no tergo basal. Também quanto aos lobos pronotais variando de ferrugíneos a castanho-escuros nos exemplares do CHILE. A pilosidade dos mesepisternos de três fêmeas coletadas em Las Cabras, Chillán, variando de castanha a creme-esbranquiçada.

Distribuição geográfica. *PERU: Cuzco, Sacsayhuaman (3585 m). CHILE: Região I, Tarapacá, Poroma; Região VI, O'Higgins; Santiago; Região VIII, Biobio; Nuble, Chillán. BOLÍVIA: La Paz. ARGENTINA: Salta; Tucumán; San Juan; Neuquén; Mendoza.

Anthidium sanguinicaudum Schwarz. 1933

(Fig. 12)

Anthidium sanguinicaudum Schwarz, 1933: 7.

Vértice com nódoas laterais amarelas, antenas com escapo preto e amarelo, no restante das antenas enegrecido e castanhoferrugíneo, tégulas em parte amarelas e em parte ferrugíneas, pernas com áreas castanhas a enegrecidas e estrias amarelas; mesoscuto, escutelo e axilas com desenhos amarelos; quarto ao sexto tergo com faixa discal amarela com sinuosidades como em A. latum, os tergos basais com faixas laterais ou máculas amarelas. Macho com o tergo distal ferrugíneo, os lobos laterais arredondados, curtos e largos; sexto esterno com espinhos laterais voltados para baixo. Fêmea com o clípeo amarelo ornado com uma área basal preta de forma triangular, paroculares inferiores amarelas; sexto tergo amarelo-ferrugíneo com dois espinhos laterais finos; escopa branca.

Distribuição geográfica. VENEZUELA: Santa Marta; Magdalena. COLOMBIA. BRASIL: Roraima; Amapá. * SURINAME: Wanica, Lelydrop.

Anthidium sertanicola Moure \& Urban, 1964

(Fig.6)

Anthidium sertanicola Moure \& Urban, 1964: 102.

Vértice com faixa ferrugínea, antenas com os artículos basais ferrugíneos e os restantes pretos, tégulas ferrugíneas, pernas ferrugíneas com amarelo na face externa das tíbias e basitassos; mesoscuto, escutelo e axilas com amarelo ou amarelo- 
ferrugíneo; tergos com faixas laterais amarelas. Macho com o sétimo tergo ornado com duas grandes máculas triangulares, com o espinho mediano arredondado, muito curto, os espinhos laterais afinando para o ápice. Fêmea com o clípeo amarelo e preto; paroculares inferiores amarelas; sexto tergo com duas nódoas alongadas amarelo-escurecidas, sem espinhos aos lados. O colorido do tegumento com variações.

Distribuição geográfica. BRASIL: Minas Gerais; Mato Grosso; São Paulo. PARAGUAI: Itapuá.

Anthidium tarsoi Urban, 2001

Anthidium tarsoi Urban, 2001: 548.

Conhecida somente a fêmea com nódoas laterais amarelas no vértice; antenas, tégulas e parte basal das pernas pretas, restante das pernas ferrugíneo; faixas amarelas laterais muito largas nos tergos, com o contorno anterior bissinuado e ornadas com pequenas nódoas pretas, sexto tergo quase todo amarelo, com pequena área preta mediana, com espinhos laterais pouco evidentes; todos os basitarsos com a face externa densoplumosa.

Distribuição geográfica. PERU, Lima, Canta (2800m).

Anthidium toro Urban, 2001

Anthidium toro Urban, 2001: 549.

Vértice com nódoas laterais amarelas; antenas e tégulas castanhas, pernas em parte ferrugíneas; tergos com faixas laterais amarelas ornadas com recortes em parte do contorno posterior, o qual resulta no estreitamento da parte mediana das faixas. Macho com os lobos laterais do sétimo tergo ferrugíneoacastanhados com a ponta voltada para o meio. Fêmea com duas máculas amarelas no clípeo e o sexto tergo com quatro projeções espiniformes.

Distribuição geográfica. CHILE: II Região, Antofagasta, Loyoques (4400m) e Saltar $(4200 \mathrm{~m})$.

\section{Anthidium vigintiduopunctatum Friese, 1904}

(Figs. 1, 23)

Anthidium vigintiduopunctatum Friese, 1904a: 182.

Vértice com nódoas amarelas laterais; antenas pretas, tégulas e pernas com amarelo e preto; máculas amarelas no dorso do mesosoma tanto no mesoscuto como no escutelo; primeiro ao quarto tergo com quatro fileiras de nódoas amarelas. Macho com quatro nódoas amarelas no quinto tergo, duas no sexto e o sétimo preto com dois pares de projeções digitiformes, as laterais mais curtas que as medianas. Fêmea com clípeo amarelo com mácula preta triangular ou triquetra; quinto e sexto tergos com um par de máculas amarelas, o sexto só com angulosidades laterais.

Distribuição geográfica. EQUADOR: Guayaquil. PERU: Piura.

Anthidium vigintipunctatum Friese, 1908

(Figs. 11, 21)
Anthidium vigintipunctatum Friese, 1908: 71.

Vértice com faixa amarela; antenas com ferrugíneo e preto, o escapo amarelo em parte; tégulas e pernas ferrugíneas; nódoas amarelas nas axilas e no escutelo; primeiro ao quarto tergo com quatro fileiras de máculas amarelas. Macho com quatro máculas amarelas também no quinto tergo, sexto com duas, sétimo enegrecido com lobos laterais arredondados e muito curtos. Fêmea com duas máculas amarelas no quinto tergo, sexto preto com um par de espinhos laterais finos; escopa branca.

Distribuição geográfica. *PERU: Lima, Vale del Lurin. ARGENTINA: *Santiago del Estero, *La Rioja; Mendoza.

Anthidium weyrauchi Schwarz, 1943

Anthidium weyrauchi Schwarz, 1943: 2

Conhecida só a fêmea com pequenas máculas amarelas laterais no vértice; antenas pretas, pernas ferrugíneas na metade distal e pretas na proximal; máculas amarelas aos lados nos cinco tergos basais, o sexto preto com angulosidades laterais, cabeça com pilosidade preta; escopa preta.

Distribuição geográfica. PERU: Ancash, Huaraz.

Agradecimentos. Aos Profs. Gerardo Lamas e Claus Rasmussen do Museo de Historia Natural "Javier Prado", Lima, PERU, pela doação de exemplares ao DZUP. Ao Prof. Albino Morimasa Sakakibara do Departamento de Zoologia, Universidade Federal do Paraná, pelas fotos que ilustram este trabalho e ao Prof. Pe. Jesús Santiago Moure pelo acesso às notas sobre os tipos das abelhas depositados em museus americanos e europeus.

\section{REFERÊNCIAS}

Cockerell, T. D. A. 1910. New and little-known bees. Transactions of the American Entomological Society 36(3): 199-249.

Cockerell, T. D. A. 1911. Descriptions and Records of Bees. XXXVII. Annals and Magazine of Natural History 8 (8): 179-192.

Cockerell, T. D. A. 1914. Bees from Ecuador and Peru. Journal of the New York Entomological Society 22: 306-328.

Cockerell, T. D. A. 1917. Some Neotropical Megachilid bees. Canadian Entomologist 49: 252-254.

Cockerell, T. D. A. 1926. Descriptions and Records of Bees. CVIII. Annals and Magazine of Natural History (9)17: 214-226.

Cockerell, T. D. A. 1927. Megachilid bees from Bolivia Collected by the Mulford Biological Expedition, 1921-22. Proceedings of the United States National Museum 71 (12): 1-22.

Ducke, A. 1907. Contribution a la Connaissance de la Faune Hyménoptérologique Du Nord-Est du Brésil. Revue d' Entomologie, Caen, 26: 73-96.

Ducke, A. 1910. Zur Synonymie der neotropischen Apidae. (Hym.). Deutsche Entomologische Zeitschrift: 362-369.

Durante, S. P. \& N. R. Díaz, 1998. Los Ejemplares tipo de Apoidea (Hymenoptera) depositados en la Coleccion del Museo de La Plata. Revista del Museo de La Plata, (n.s.), Serie Tecnica y Didactica 33: $1-14$.

FABricius, J. C. 1775. Systema Entomologiae, sistens insectorum classes, ordines, genera, species, adiectis synonymis, locis, descriptionibus, observationibus. Flensburgi et Lipsiae, Korte. xxviii +832 p. 
Fabricius, J. C. 1804. Systema Piezatorum. Brunsvigae. xiv +15 440+1-32 p.

FrIeSE, H. 1904a. Beiträge zur Bienenfauna von Chile, Peru und Ecuador. (Hym.). Zeitschrift für systematische Hymenopterologie und Dipterologie IV (1-6): 180-188.

Friese, H. 1904b. Ueber einige Bienen von Chile. Zeitschrift für systematische Hymenopterologie und Dipterologie IV (1-6): 303-304.

Friese, H. 1908. Die Apidae (Blumenwespen) von Argentina nach den Reisenergebnissen der Herren A. C. Jensen-Haarup und P. Jörgensen in den Jahren 1904-1907 [reprint]. Flora og Fauna 10: 1-94.

Friese, H. 1909. Zur Synonymie der Apiden. Deutsche Entomologische Zeitschrift, Beiheft: 124-128.

Friese, H. 1910. Zur Bienenfauna des südlichen Argentinien (Hym.). Zoologische Jahrbücher, Abteilung für Systematik, Geographie und Biologie der Tiere 29: 641-660.

FrIeSE, H. 1913. II. Nachtrag zu bienen Afrikas. Zoologische Jahrbücher, Abteilung für Systematik, Geographie und Biologie der Tiere 35: $561-592$

Friese, H. 1917. Neue Arten der Bienengattung Anthidium (Hym.) (Paläarktische Region und von Formosa). Deutsche Entomologische Zeitschrift (H. I): 49-60.

Friese, H. 1920. Neue Arten der Bauchsammler. (Hym.). Deutsche Entomologische Zeitschrift: 49-55.

Friese, H. 1925. Neue neotropische Bienenarten, zugleich II. Nachtrag zur Bienenfauna von Costa Rica. Stettiner Entomologische Zeitung 86: 1-41

Friese, H. 1930. Die Schmarotzerbienengattung Osiris Sm. (Hym.). Stettiner Entomologische Zeitung 91: 1103-127. [Corrigenda: 127].

GriBodo, J. 1894. Matériaux pour servir à l'étude de la Faune Entomologique du Chili (I). Actes de la Societé Scientifique du Chili IV: 199 242.

Griswold, T. L. \& C. D. Michener, 1988. Taxonomic observations on Anthidiini of the Western Hemisphere (Hymenoptera: Megachilidae) Journal of the Kansas Entomological Society 6 (1): 22-45.

Herbst, P. 1907. Zur synonymie der Apiden. Zeitschrift für systematische Hymenopterologie und Dipterologie 7: 130131.

Herbst, P. 1921. Üeber einige chilenische Hymenopteren, welche Gribodo erwähnt. Stettiner Entomologische Zeitung 82: 102-107.

Joergensen, P. 1912. Revision der Apiden der Provinz Mendoza, Republica Argentina. Zoologische Jahrbücher, Abteilung für Systematik, Geographie und Biologie der Tiere 32: 89-162.

Latreille, P. A. 1810. Considérations générales sur l'ordre naturel des animaux composant les classes des Crustacés, des Arachnides, et des Insectes. Paris. Schoell. $444 \mathrm{p}$

Linnaeus, C. 1758. Systema Naturae vol I, ed. 10. Stockholm. 842 p.

Michener, C. D. 1948. The generic classification of the Anthidiine Bees (Hymenoptera, Megachilidae). American Museum Novitates 1381: $1-29$.

Michener, C. D. 2000. The Bees of the World. Baltimore \& London, The John Hopkins University Press, xiv +913 p.

Moure, J. S. 1947. Novos agrupamentos Genéricos e algumas espécies novas de abelhas sulamericanas. Museu Paranaense, Publicações Avulsas 3: 1-37.

Moure, J. S. 1957. Nuevos Anthidiinae para Chile (Hymenoptera, Apoidea). Revista Chilena de Entomologia 5: 205-218.

Moure, J. S. 1960. Abelhas da Região Neotropical descritas por Gribodo. Boletim da Universidade Federal do Paraná, Zoologia, 1: 118 .

Moure, J. S. \& D. URban, 1964. Revisão das espécies brasileiras do gênero Anthidium Fabricius, 1804. (Hym. - Apoidea). Anais do II Congresso Latino-Americano de Zoologia I: 93-114.

Reed, E. P. 1930. Un Nuevo Ápido Chilense. Revista Chilena de Historia Natural 34: 375.

Ruiz, F. 1935. Algunas notas entomologicas. Revista Chilena de Historia Natural 39: 271-278.

Ruiz, F. 1938. Nuevas especies de abejas chilenas. Revista Chilena de Historia Natural 42: 148-153.

Ruzz, F. 1940. Apidologia chilena. Revista Chilena de Historia Natural 44: 281-377.

Schletterer, A. 1890. Apidarum species novae descriptae. Entomologische Nachrichten XVI (15): 225-238.

Schrotткy, C. 1902. Ensaio sobre as abelhas solitarias do Brazil. Revista do Museu Paulista 5: 330-613.

Sснготтку, C. 1910. Neue südamerikanische Arten Bienengattung Anthidium Fabr. Wiener Entomologische Zeitstung 29 (Heft 78): $267-271$.

Schwarz, H. F. 1933. Some neotropical Anthidiinae: Anthidium, Heteranthidium, and Dianthidium. American Museum Novitates 624: 1-27.

Schwarz, H. F. 1943. Bees of the genus Anthidium from Peru. American Museum Novitates 1242: 1-6.

Sмiтн, F. 1854. Catalogue of Hymenopterous Insects in the Collection of the British Museum. Part 2. London: 199-465.

Sмiтн, F. 1879. Descriptions of New Species of Hymenoptera inthe Collection of the British Museum. London. XXI $+240 \mathrm{p}$.

Spinola, M. 1851. In: Gay, C. Historia Fisica y Politica de Chile. Zoologia. (Himenopteros) 6: 153-569. Paris, Casa del Autor.

StRAND, E. 1910. Beiträge zur Kenntnis der Hymenopterenfauna von Paraguay. Zoologische Jahrbbücher, Abteilung für Systematik, Geographie und Biologie der Tiere 29: 455-562.

Toro, H. 1986. Lista prelimirar de los Ápidos Chilenos (Hymenoptera: Apoidea). Acta Entomológica Chilena 13: 121-132.

Toro, H. \& S. Rodríguez 1998. Los Anthidiini de Chile: Clave para Especies (Himenoptera: Megachilidae). Acta Entomológica Chilena 22: $63-78$.

Toro, H. \& F. Rojas 1970. Los Anthidiinae (Hymenoptera - Apoidea) de la província de Valparaíso. Boletim del Museo Nacional de Historia Natural, Chile 31: 125-184.

Urban, D. 1997. Anthidium larocai sp. n. do Mato Grosso e ocorrência de Anthidium sanguinicaudum Schwarz, 1933 no norte do Brasil (Hymenoptera, Magachilidae). Acta Biológica Paranaense 26 $(1,2,3,4): 33-38$.

Urban, D. 2001. Espécies novas d Anthidium Fabricius do Chile, Argentina e Peru (Megachilidae, Hymenoptera). Revista brasileira de Zoologia 18 (2): 539-550. 